\title{
Bedding, hearths, and site maintenance in the Middle Stone Age of Sibudu Cave, KwaZulu-Natal, South Africa
}

\author{
Paul Goldberg • Christopher E. Miller • \\ Solveig Schiegl • Bertrand Ligouis • Francesco Berna • \\ Nicholas J. Conard • Lyn Wadley
}

Received: 31 October 2008 / Accepted: 6 April 2009/Published online: 13 May 2009

(C) Springer-Verlag 2009

\begin{abstract}
Micromorphological analysis of sediments from the Middle Stone Age site of Sibudu Cave, KwaZulu-Natal, South Africa, provides a high-resolution sequence and evidence of site formation processes of predominantly anthropogenic deposits. This methodology allows for a detailed interpretation of individual anthropogenic activities, including the construction of hearths and bedding and the maintenance of occupational surfaces through the sweep out of hearths and the repeated burning of bedding. This analysis also provides a context for evaluating other studies at the site relating to magnetic susceptibility, paleobotany, paleozoology, anthracology, and studies of ochre.
\end{abstract}

Keywords Micromorphology · Organic petrology · Middle Stone Age · Combustion features · Char · Charcoal · Secretinite

P. Goldberg • F. Berna

Department of Archaeology, Boston University,

Boston, MA, USA

P. Goldberg

e-mail: paulberg@bu.edu

P. Goldberg $\cdot$ C. E. Miller $(\bowtie) \cdot$ S. Schiegl $\cdot$ B. Ligouis $•$

N. J. Conard

Institut für Ur- und Frühgeschichte und Archäologie des

Mittelalters, Abteilung Ältere Urgeschichte und Quartärökologie,

Eberhard-Karls-Universität Tübingen,

Tübingen, Germany

e-mail: christopher.miller@uni-tuebingen.de

L. Wadley

Institute for Human Evolution and School of Geography,

Archaeology and Environmental Studies,

University of the Witwatersrand,

Johannesburg, South Africa

\section{Introduction}

The site of Sibudu has been studied intensively over the last decade, and numerous in-depth publications have appeared by specialists in a variety of fields that include lithic studies, paleobotany, paleozoology, paleomagnetism, and dating (e.g., Wadley 2006; Wadley and Jacobs 2004, 2006). Although this work has been meticulous and has been carefully tied to the fine stratigraphic units recognized during excavation, results from these studies-as is generally the case for archaeological excavations-are somewhat synoptic in nature. In other words, lithostratigraphic units were recognized at the site and materials collected from them were analyzed. What is underdeveloped, however, is an integration of the finds with the specific context from which individual objects (e.g., seeds, charcoal, microliths, and bones) are confined. Are hearths, for example, composed of woody charcoal, nonwoody plants (e.g., grasses), or mixtures of both? What is the arrangement of these combustibles in the fireplace: is charcoal always at the base of the hearth overlain by ashes, or are ashes intimately mixed with charcoal? Similarly, are phytoliths in direct physical association with specific types of charred remains? Can small gaps be recognized that attest to lack of occupation that are not apparent in the field? In other words, examination of the microstratigraphic context at a microscopic scale has so far not been adequately addressed here and in many if not most excavations, particularly where anthropogenic components are concerned (Courty 2001).

Since the Sibudu deposits are largely anthropogenic, it is critical to investigate them intact with their original integrity maintaining the highest possible degree of resolution to resolve even single episodes of human activities. It is now becoming clear that anthropogenic deposits contain microscopic information about past human lifeways with 
equal if not greater value than other macroscopic facets of the archaeological record typically studied, such as bones, lithics, and plants (Courty 2001; Goldberg and Macphail 2006; Berna et al. 2007).

The technique of micromorphology is particularly well suited to provide the basis for microscopic highresolution study of anthropogenic sediments and the human events and activities that led to their formation (Courty 2001; Courty et al. 1989; Berna and Goldberg 2007). Micromorphological and microscopic analysis permits an integration of macroscopic and microscopic evidence into the microstratigraphy and therefore allows for the contextualization of artifacts and features with a high degree of resolution.

The aim of this study is to address the site formation processes-anthropogenic, biogenic, diagenetic, and geogenic - operating at Sibudu Cave, using micromorphological techniques of intact deposits. Although stress is placed on teasing out human activities and interpreting the underlying human behavior responsible for the site's primarily human-derived deposits, we will attempt to relate the micromorphology to results of other specialists at the site (Wadley 2006) and show how more informed interpretations can be made if the micromorphological data of intact deposits are taken into account [e.g., geoarchaeology (Pickering 2006); magnetic studies (Herries 2006)].

\section{Site setting and stratigraphy}

The site of Sibudu is situated within a sandstone cliff reentrant that overlooks the Tongati River. It is about 40 $\mathrm{km}$ north of Durban and $15 \mathrm{~km}$ inland from the Indian Ocean (Figs. 1 and 2; Wadley and Jacobs 2006). The bedrock is comprised of sandstones of the Natal Group, which at the site consist of reddish quartz and feldspar-rich medium sand and some silt (Pickering 2006); clay can be seen in thin section as an interstitial binder between the coarser grains.

The stratigraphy has been well described in a number of papers (Jacobs et al. 2008; Wadley and Jacobs 2004, 2006) and accompanied by several OSL dates (Table 1). Overall, however, the deposits are predominantly anthropogenic, with numerous lenses of ashy and charcoal-rich units that appear to represent, at least in the field, intact hearths. Many of these remains of combustion-related units are lenticular and thus difficult to trace horizontally over distances of more than tens of centimeters (Wadley 2006), explaining the discrepancies between the general stratigraphic sequence as presented in Table 1 and the actual stratigraphic sequence collected within the micromorphological samples, as presented in Table 2. In some areas, excavators noted both individual circular hearths in outline, as well as superposed burning episodes, although individual

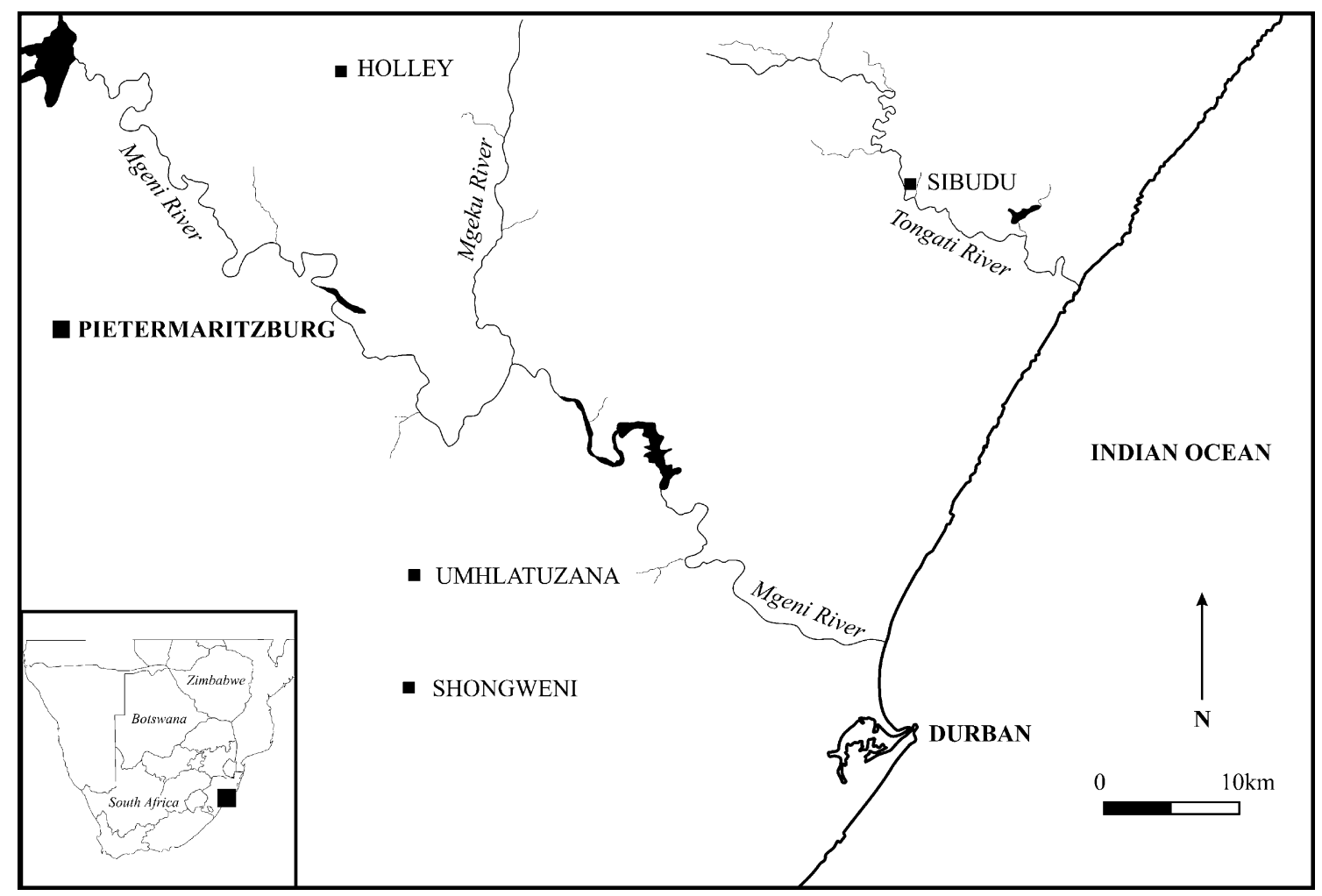

Fig. 1 Location of Sibudu Cave 


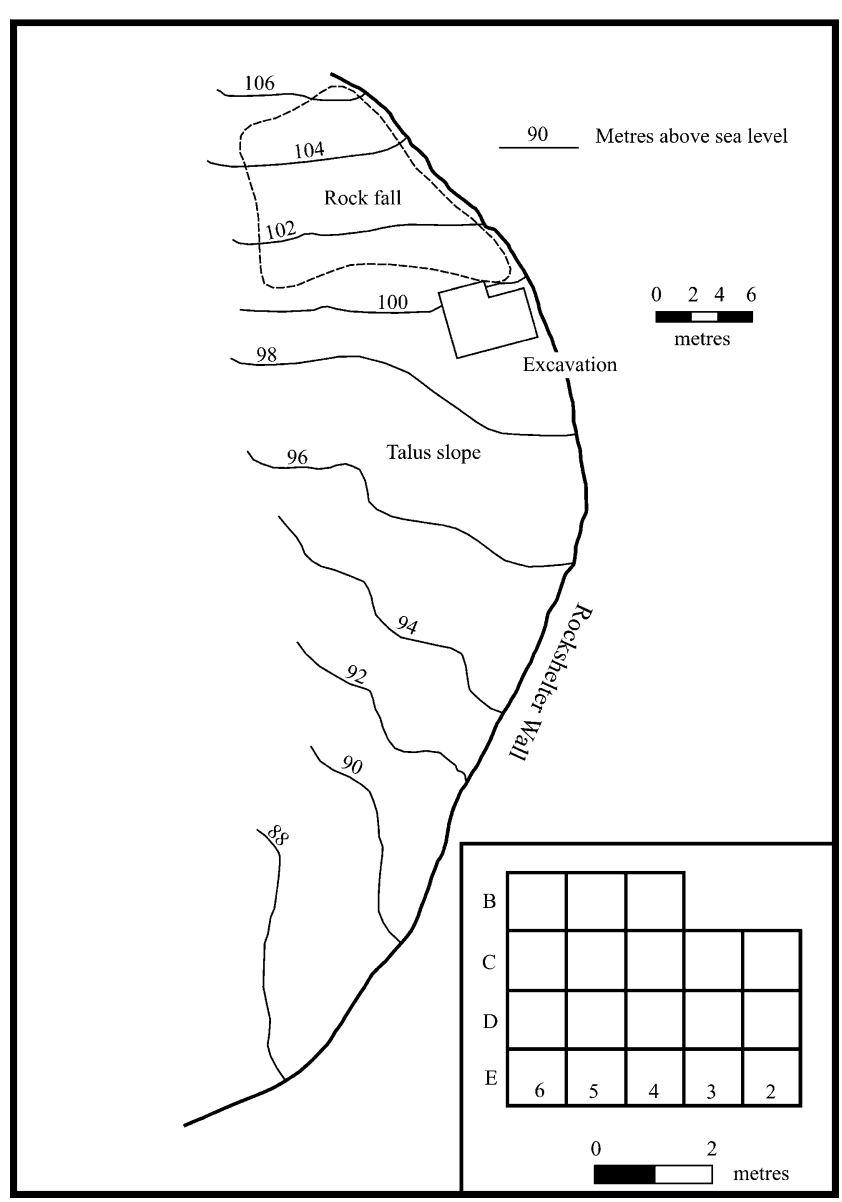

Fig. 2 Excavation plan of Sibudu cave

events in the field were difficult to distinguish (cf., micromorphological results below). Wadley noted,

Generally, hearths and the sediments that separate them are almost indistinguishable from one another based on their phytolith content, suggesting that there may once have been more hearths than are currently recognisable (Schiegl et al. 2004: 192). Ash may have been spread and trampled (Wadley 2006: p. 324).

\section{Methods}

Undisturbed samples were collected in different excavation seasons by two of us (S. Schiegl in 2002, P. Goldberg in 2004, and S. Schiegl in 2005; Table 2; Fig. 3). We removed them either by cutting out blocks and wrapping them tightly with toilet paper and packaging tape or, where too loose or unconsolidated, by using plaster bandages to preserve sample integrity (see Goldberg and Macphail 2003 for details). Samples collected by P. Goldberg were processed at the Micromorphology Laboratory, Boston University, where they were partially unwrapped and oven dried for several days at $60^{\circ} \mathrm{C}$. They were then impregnated with unpromoted polyester resin (Advance Coatings, Westminster, MA, USA) and diluted with styrene at a ratio of seven parts resin to three parts styrene; the mixture was catalyzed using MEKP. A similar procedure was carried out by S. Schiegl in Tübingen, but using a different resin, Viscovoss $\mathrm{N} 50 \mathrm{~S}$. After gelling, the blocks were heated overnight at $60^{\circ} \mathrm{C}$ and then trimmed to size for thin sectioning. P. Goldberg's slides measured $50 \times 75 \mathrm{~mm}$ and were manufactured by Spectrum Petrographics (Vancouver, WA, USA); those in Germany were somewhat larger $(60 \times 80 \mathrm{~mm})$ and made by Th. Beckmann (Schwülper-Lagesbütel, Lower Saxony, Germany). All thin sections were ground to a uniform thickness of $30 \mu \mathrm{m}$. The thin sections were analyzed and described using standard micromorphological nomenclature (Courty et al. 1989; Stoops 2003).

Organic petrography analyses were performed to investigate the organic constituents and especially organic residues from the combustion features (Berna and Goldberg 2007). These analyses were made on impregnated blocks that corresponded to the mirror slices employed to make the thin sections. The surface of the blocks were polished with 1-mm diamond suspension and with $0.7-\mu \mathrm{m}$ alumina $\left(\mathrm{Al}_{2} \mathrm{O}_{3}\right)$ suspension, following techniques developed for coal sample preparation (Taylor et al. 1998). The blocks were studied using reflectance and UV microscopic techniques to identify organic-derived combustion materials not commonly identified in standard micromorphological examination. Reflectance, which is measured as a percentage of incident light reflected by the components at the polished surface of the impregnated blocks, reveals the thermal maturity of the material. Reflectance measurements can therefore be used to investigate the extent to which organic material has been heated. Identification and classification of organic components is based on morphological characteristics. For a more detailed description of the application of organic petrographic methods to archaeology and combustion material, see Schiegl et al. (2004) and Ligouis (2006).

\section{Results}

Micromorphology Micromorphological analysis revealed not only the mineral and organic components in the deposits but, as importantly, the fabric of these elements (the total organization and spatial arrangement of the constituents of the material), both with regard to themselves and to other components. Thus, investigation of the composition and texture, as well as the fabrics in true space, allows us to make more robust interpretations about where such materials came from, how they were deposited, and how they were modified after they were deposited. Below, we present the results of micromorphological observations in two parts. The first provides an account of the basic organic and mineral 
Table 1 Stratigraphy of Sibudu Cave, after Schiegl and Conard 2006

Strata Field observations

Absolute ages

(C14 ages in

italics; OSL ages

in plain text)
Iron age sequence

BSV

BSS

Brown sand with stones

Eastern MSA sequence

Co

$\mathrm{Bu}$

LBMOD

$\mathrm{MC}$

Mou, DMou, LMou

Ore

Ore2 and $\mathrm{PB}$

$\mathrm{Cad}$

$\mathrm{Pu}$

RD

Northern MSA sequence MOD

OMOD

$\mathrm{RSp}$

YSp

BSp

BSp2

SPCA

BL

Or

Mi

SS, Che

$\mathrm{Eb}$

Ma

MY, BO, BP,

$\mathrm{P}(\mathrm{Iv}, \mathrm{BM})$

OP

$\mathrm{Su}, \mathrm{Su} 2$

Small lenses

Dark-brown silt its rock spalls

A black, ashy layer $\mathrm{BO}, \mathrm{BP}$, and $\mathrm{P}$ hearth within P.
Coffee-colored, sandy deposit

Light gray, sandy silt with lots of small roof spalls

Thin light-brown lens with white flecks of gypsum

Small white ash lens that does not reach the eastern section wall

Deep hearths called ore 2 and PB belong to ore

Darker-brown deposit in square $\mathrm{C} 2$ and beneath this is a small patch of orange sandy silt, $\mathrm{Pu}$

Small patch of orange sandy silt beneath Cad

$\mathrm{RD}$ is an organic-poor gray layer with a great many spalls and stone tools; it may be a lag deposit adjacent to RSp in some squares and in place of RSp in the eastern part of the grid, but the relationship between the two layers is not clear

The youngest layer at the top of the northern sequence; a mottled brown silty sand with flecks of white ash, gypsum, and charcoal

OMOD below MOD, in squares B4, C2, C3, and C4, is a thick member comprising a palimpsest of hearths with orange-brown burnt earth lenses at their bases, black carbonized layers in their centers, and white, cream, or gray ash crowns

A reddish-brown layer with white chalk-like grains of gypsum and calcium carbonate; it is present in all but two squares of the excavation grid and is thus a good marker layer for the site

A discontinuous yellow-beige sandy silt

A brown sandy silt with black and white flecks of charcoal and gypsum

It contains the same brown matrix as BSp, but it contains many interfingering hearths and ash lenses

A camel-colored or gray-white sand that contains calcium carbonate; darker deposits fill small pits that may be solution cavities in this layer

A thin discontinuous black lens

It is colored orange to beige

Another black layer; distinguished by gypsum crystals that cling to

Che is a thin, disjointed, and chestnut-brown fine sand that seems to be part of layer SS, a stony and partly compacted sand marbled with yellow, beige, and pink-orange (the deepest layer excavated in the main part of the excavation grid)

A mahogany-brown silt that rests on several discontinuous layers: MY,

MY looks like SS; BO is a burnt-ochre silt; BP is a brown silt with white flecks; $\mathrm{P}$ is an orange-brown sandy silt with white flecks of gypsum; the small lenses Iv (white ash) and BM (black ash) are probably parts of a

A discontinuous, orange sand with crumbs of gypsum and charcoal.

Thin, concreted, gritty layers of sulfur-yellow sand; this color is unique in the sequence; the two sulfur-colored layers are separated and underlain by chocolate-colored lenses, $\mathrm{Ch}$ and $\mathrm{Ch} 2$
$61.5 \pm 2.2 \mathrm{ka}$

$960 \pm 25$ b.p. (Pta-8015), calibrated to $A D$ 1044-1171

$37.1 \pm 1.5 \mathrm{ka}$

$36.7 \pm 1.7 \mathrm{ka} ; 42300 \pm$ 1300 b.p. (Pta-8017)

$50.4 \pm 1.8 \mathrm{ka}$

$49.0 \pm 2.0 \mathrm{ka}$

$49.7 \pm 1.8 \mathrm{ka}$

$50.3 \pm 2.1 \mathrm{ka}, 50.2 \pm 1.7 \mathrm{ka}$

$48.4 \pm 1.7 \mathrm{ka}$

$61.3 \pm 2.0 \mathrm{ka}$

$56.2 \pm 1.9 \mathrm{ka}(\mathrm{SS})$

$64.1 \pm 2.9 \mathrm{ka}(\mathrm{P})$ 
Table 1 (continued)

\begin{tabular}{|c|c|c|}
\hline Strata & Field observations & $\begin{array}{l}\text { Absolute ages } \\
\text { (C14 ages in } \\
\text { italics; OSL ages } \\
\text { in plain text) }\end{array}$ \\
\hline $\mathrm{Ch}, \mathrm{Ch} 2$ & Chocolate-colored lenses & $61.6 \pm 1.9 \mathrm{ka}(\mathrm{Ch} 2)$ \\
\hline G1 & A gray ash in the northeastern corner of square B5 & \\
\hline Y1 & A yellow sandy silt with some spalls & $59.4 \pm 2.4 \mathrm{ka}$ \\
\hline $\begin{array}{l}\text { B/Gmix, } \\
\text { B/Gmix2, } \\
\text { BL2, BL3 }\end{array}$ & $\begin{array}{l}\mathrm{B} / \mathrm{Gmix} \text { and } \mathrm{B} / \mathrm{Gmix} 2 \text { are mottled brown-gray ashy deposits with } \\
\text { some spalls; BL2 and BL3 are dark ash units within B/Gmix }\end{array}$ & $59.4 \pm 2.3$ (B/Gmix) \\
\hline W & A white ash layer in the northeastern corner of square B5 & \\
\hline BOr & A deep-brown organic-rich deposit under B/Gmix 2 & \\
\hline $\begin{array}{l}\text { Ymix, YA1, } \\
\text { YA2 }\end{array}$ & All are yellow ashy silts & \\
\hline DRG & $\begin{array}{l}\text { A small lens that occurs in only part of the trial trench; it is loose silt } \\
\text { with small rock spalls and it is dark reddish gray }(10 \text { YR } 3 / 1)\end{array}$ & \\
\hline GS/GS2 & $\begin{array}{l}\text { GX is gray ( } 5 \text { YR } 5 / 1) \text { silty sand with ash and many small rock spalls; } \\
\text { GS2 is a spit to artificially divide this layer }\end{array}$ & \\
\hline PGS & This is loose pinkish-gray sand (5 YR 6/2) with few rock spalls & \\
\hline RGS, RGS2 & $\begin{array}{l}\text { Loose reddish-gray sand ( } 5 \text { YR 5/2); RGS } 2 \text { artificially splits this } \\
\text { thick layer }\end{array}$ & \\
\hline $\begin{array}{l}\text { LBG, LBG2, } \\
\text { LBG3, LBG4 }\end{array}$ & $\begin{array}{l}\text { A series of light brownish-gray layers }(10 \text { YR } 6 / 2) \text { that are soft and } \\
\text { silty with a few small rock spalls; LBG } 2, \text { LBG 3, and LBG } 4 \text { are } \\
\text { arbitrary divisions of LBG; big rocks begin to encroach on the two } \\
\text { squares during the LBG layers }\end{array}$ & \\
\hline BS & $\begin{array}{l}\text { Loose brown sand with rock spalls and many encroaching rocks. } \\
\text { At the base of this layer, a floor of rock stopped excavations; the rock } \\
\text { may be bedrock, but it could be rock fall that can be removed when } \\
\text { squares adjacent to the trial trench are excavated }\end{array}$ & \\
\hline
\end{tabular}

components that were found in virtually all the slides examined. The second part considers the arrangement of these constituents as represented by distinct and recurrent groups of similar composition and organization; these groups are designated as microfacies (Flügel 2004).

Components A summary of the micromorphological components is presented in Table 3. Most of these basic components are found in all samples, although considerable variations occur in their proportions and organization from layer to layer.

Bone, most of it burnt, was found in all samples. It usually consisted of sand-sized fragments, sometimes rounded or subrounded, although angular splinters were also noted. The bone fragments were sometimes chaotically distributed throughout the matrix, although in certain instances they formed beds or specific layers. Frequently, the bone formed "stringers" of fragments, which had the appearance of being crushed in place.

Plant materials and derivatives make up the largest majority of components found in the thin sections. Charcoal, both woody and fibrous, is abundant, although some pieces appear only humified, as seen in oblique incident light. Some woody pieces of charcoal have clearly identifiable structures typical of woody plants (Kathleen Deckers 2008, personal communication). The wood usually appears angular but, in some instances, can also be rounded. The fibrous plant material usually forms layers of finely laminated material, not always charred but probably humified or reddened [cf. (Sievers and Wadley 2008)]. The long fibers, particularly the charred ones, are commonly found interfingered with or as isolated stringers within layers of phytoliths.

Phytoliths are also an important component of sediments at Sibudu, sometimes being the sole component of a layer. Many different types of phytoliths appear to be represented, including forms that resemble cells and plant structures. Many appear to be rod-shaped long cells and cones, which are typical of sedges (Arlene Rosen 2008, personal communication). The phytoliths in some cases form laminated layers (see below, MF type 4), often associated with charred fibrous material. Layers of nothing but phytoliths are also found that do not exhibit any lamination (see MF type 4A). Although these layers of pure phytoliths are quite striking, phytoliths do occur in most samples, usually as isolated individuals. However, the amount of phytoliths and the occurrence of phytolith layers appear to increase in the upper portion of the sequence at Sibudu. Some forms of phytoliths found in slides from Sibudu appear vesicular, resembling "siliceous aggregates" as described by Schiegl and Conard (2006). These bodies often appear as isotropic aggregates that incorporate sand- 
Table 2 List of micromorphological samples collected at Sibudu Cave

\begin{tabular}{|c|c|c|}
\hline Sample number & Square & Stratigraphic unit(s) \\
\hline \multicolumn{3}{|c|}{ S. Schiegl SAMPLES } \\
\hline SS-1 & B4/B5 line (east face of B5) & $\begin{array}{l}\text { BL } \\
\text { Or } \\
\text { Che } \\
\mathrm{SS} \\
\mathrm{SS} \text { hearth } \\
\mathrm{Eb}\end{array}$ \\
\hline SS-2 & B5B6/A5A6 line (north face of B5 and B6) & $\begin{array}{l}\text { BSP } \\
\text { SPCA } \\
\text { Hearth in Or } \\
\text { Mi }\end{array}$ \\
\hline SS-3 & B4/B5 line (east face of B5) & $\begin{array}{l}\text { B/G Mix2 } \\
\text { Pink } \\
\text { WA hearth } \\
\text { YA } \\
\text { BUYA } \\
\text { YA2 } \\
\text { BUYA2 }\end{array}$ \\
\hline SS-4 & North face of B4 & $\begin{array}{l}\text { RSP } \\
\text { BSP }\end{array}$ \\
\hline SS-5 & North face of B4 & OMOD \\
\hline SS-6 & B4/B5 line (east face of B5) & $\begin{array}{l}\mathrm{Ma} / \mathrm{BO} \\
\mathrm{BM} \\
\text { Pox }\end{array}$ \\
\hline $\begin{array}{l}\text { SS-Daga Floor } \\
\text { P. Goldberg SAN }\end{array}$ & P. Goldberg SAMPLES & Iron Age burnt hut floor \\
\hline SIB-04-1 & B4/B5 line & $\begin{array}{l}\text { Pinkish-gray sand } \\
\text { Gray sand } 2\end{array}$ \\
\hline SIB-04-2 & B4/B5 line & $\begin{array}{l}\text { Gray rocky } \\
\text { Hearth in gray rocky }\end{array}$ \\
\hline SIB-04-4 & B4/B5 line & $\begin{array}{l}\text { Midnight } \\
\text { Orange under midnight } \\
\text { Chestnut } \\
\text { SS } \\
\text { Ebony } \\
\text { Ebony hearth }\end{array}$ \\
\hline SIB-04-5 & B4/B5 line & $\begin{array}{l}\text { Pox } \\
\text { O[range] pox } \\
\text { B[rown] pox } \\
\text { G1 }\end{array}$ \\
\hline SIB-04-6 & North face of B4 & RSP \\
\hline
\end{tabular}

Samples designated SS were collected by Solveig Schiegl in 2002 and 2005. Samples designated PG were collected by Paul Goldberg in 2004
In addition to phytoliths, other microbotanical remains were found in the slides from Sibudu, including spores and diatoms. The spores (usually $20-30 \mu \mathrm{m}$ in diameter) were found in only one slide (SS-5C) and generally occurred within localized domains. Diatoms were found in just one slide (SS-5A) and occurred within a clast of orange clay, probably originating from the Tongati river valley. 
Fig. 3 Field photos showing sample locations (see Table 2). a Location of samples SIB-04-5 and SS- 6 along the B4/B5 line. b Location of samples SIB-04-2 and SIB-04-1 along the B4/B5 line. c Location of samples SS4, SS-5, and SIB-04-6 at the north face of B4
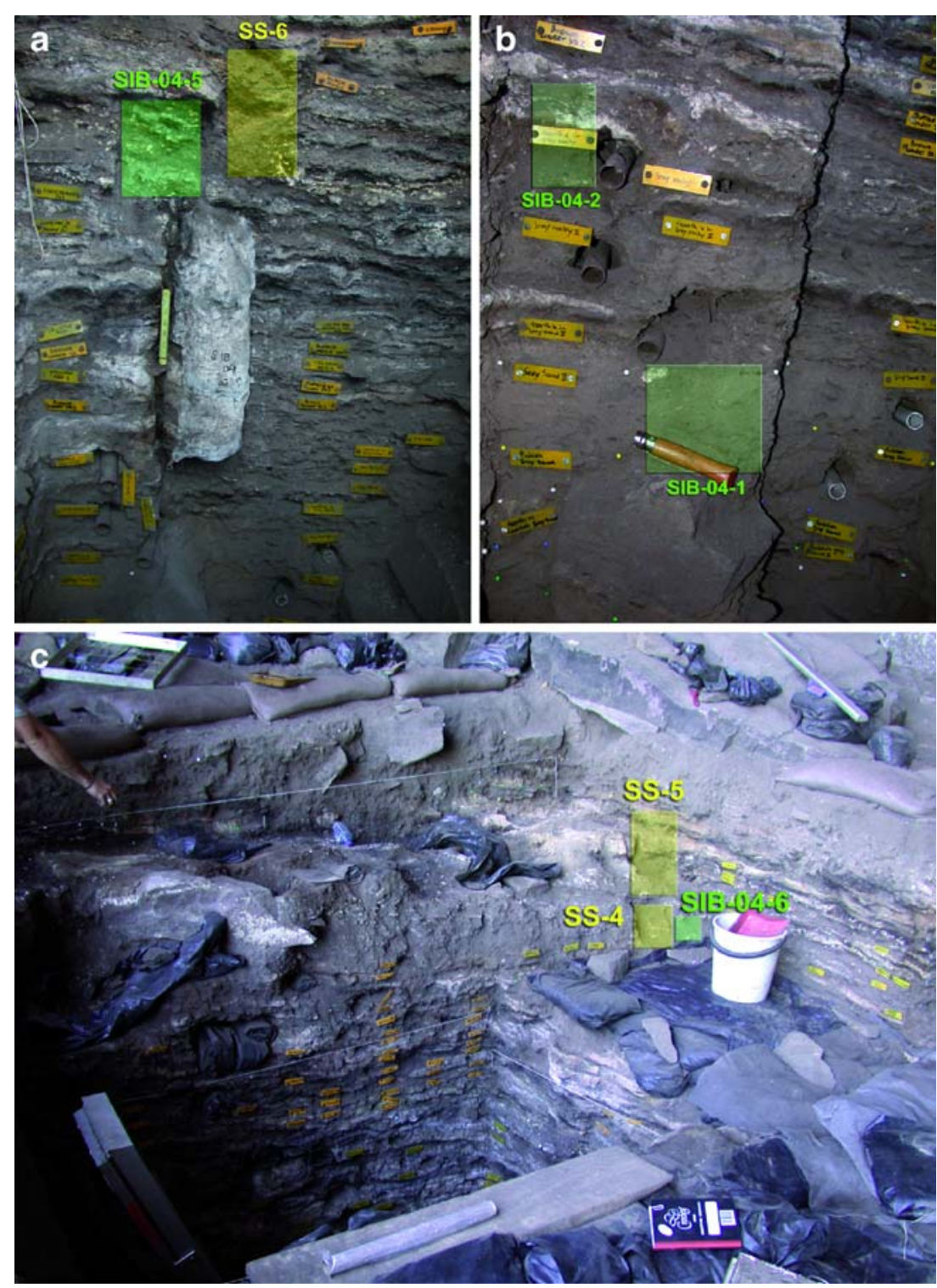

An interesting component found in only one slide (SS6A) are rounded 1.5-mm-diameter aggregates of fine organic matter, containing fragments of charcoal, bone, and quartz silt. They are found within a single layer, and we interpret them as small mammalian excrement or fecal pellets.

The clastic components of the sediment at Sibudu span the range of size from centimeter-sized pieces of local bedrock to silt and clay. The larger clasts $(1$ to $2 \mathrm{~cm})$ found in the samples are typically elongated and angular, usually oriented parallel to the bedding surface, although vertical and subvertical clasts were noted in some layers. The clasts consist of slightly metamorphosed sandstone and siltstone, representing roof fall from the local bedrock of the rock shelter. Some components within this size class were composed of cryptocrystalline silica and probably are lithic artifacts that were included in the sample block.
Sand- to granule-sized pieces of weathered and unweathered volcanic rock were also found in some samples. These appear to be derived from doleritic dikes which crosscut the metamorphosed sand and siltstone bedrock of the region (Pickering 2006).

A sand- and silt-sized component of the sediment is noted in all samples. The sand is usually angular to subangular, although some grains exhibit subrounding. The sand usually consists of quartz or feldspar, although sand-sized pieces of mica and clay (both fresh and weathered) were also present. Like the larger sand- and siltstone clasts, the sand-sized grains were derived from the physical and chemical deterioration of the rock shelter wall. It is possible that some grains were "tracked in" to the rock shelter by humans or animals, although this was probably a relatively minor process.

Silt grains occur as a small component of all samples and are usually very fine $(20-30 \mu \mathrm{m})$, consisting mostly 
Table 3 Components identified in thin section from micromorphological samples from Sibudu Cave

Component Description and comments Representative thin sections

Bone (and teeth)

Charcoal: wood

Charcoal: fibrous

Spores

Diatoms

Phytoliths

Siliceous aggregates

Clastic elements

Roof fall and

lithic artifacts

Volcanic rocks
Generally sand to centimeter-sized pieces

Rounded to subrounded; angular splinters

Dark brown to yellow to white in color

Burned and unburned; some calcined

Bedded and chaotically distributed; in some cases, fragments are concentrated in layers or broader bands (e.g., SS-5B) and in stringers

Locally crushed in place, with no displacement

Sand-sized up to centimeter-sized

Varies from nondescript pieces and chunks to those with clear vessel and tracheid structures

Mostly charred, but many appear only to be humified or reddened (particularly as seen in oblique incident light - OIL)

Mostly angular but some are clearly well rounded

Isolated pieces to bedded ones

Thin fibrous grains of charred plant material generally aligned within layers but also distributed throughout finer-grained matrix material (of varied composition)

Mostly charred but many appear only to be humified or reddened (particularly as seen in OIL)

Commonly interfingers with or occurs as thing stringers in phytolith layers

Circular brown in color

Generally 20 to $30 \mu \mathrm{m}$ across

Occur only in certain slides (e.g., SS-5C)

Dispersed throughout sediment but commonly occur as local domains in certain slides and regularly in concentrated zones

Occurs predominantly in one slide within chunk of orange clay,

likely derived from river valley

Several unidentified types

Many types

Occur as microfacies type 4: microlaminated phytoliths with little or virtually no mineral or organic matrix

Also occur as in microfacies type 4A where they are nonlaminated and mixed with rock fragments, charcoal, and crushed bone

Consist of many plant types (nonidentified), including cells and vesicular siliceous types, which may be taken for "siliceous aggregates"

Illustrated in Schiegl et al. (2004) but intact presence as grains within thin sections is not clear

Commonly occur as clear isotropic aggregates in XPL that contain phytoliths and silt-sized quartz grains

Seem to be detrital or organically formed

Are commonly found within layers of phytolith ashes that are not melted; thus, the siliceous aggregates at Sibudu are probably not produced by the melting of phytoliths

Possibly equivalent to "bubbly" siliceous grains with vesicular structure [c.f., Schiegl et al. (2004) Figs. 6 and 7]

Generally elongated and quite angular chunks of slightly metamorphosed sandstone and some siltstone

$1-2 \mathrm{~cm}$ across

Generally parallel to bedding although in some cases clasts are vertical

Generally sand- to granule-sized

Weathered and unweathered dolerite and other volcanic rocks occurring as traces within some samples
SS-6B

SS-5C

All; SS-4; SS-6B

SS-5B; SS-5C

SS-5A

SS-5B; SS-5C SS-6A

Lithic artifact:

SS-5C

Eboulis: SS-5A;

SS-5C

SS-5D 
Table 3 (continued)

\begin{tabular}{|c|c|c|}
\hline Component & Description and comments & Representative thin sections \\
\hline \multirow[t]{2}{*}{ Silt } & $\begin{array}{l}\text { Occurs in trace amounts in most samples } \\
\text { Very fine-sized, typically } \sim 20-30 \mu \mathrm{m}\end{array}$ & \multirow[t]{2}{*}{ All } \\
\hline & $\begin{array}{l}\text { - Mostly quartz, but some traces of mica, and even fewer } \\
\text { heavy minerals }\end{array}$ & \\
\hline \multirow[t]{3}{*}{ Sand } & $\begin{array}{l}\text { Predominantly quartz and feldspar, but other individual grains } \\
\text { of minerals from bedrock also observed (mica, clay), which are } \\
\text { both fresh and weathered } \\
\text { Angular to subangular; much fewer subrounded }\end{array}$ & \multirow[t]{3}{*}{ SS-4 } \\
\hline & $\begin{array}{l}\text { Derived from breakdown of shelter wall and ceiling; possibly } \\
\text { some tracking in of grains but relatively minor }\end{array}$ & \\
\hline & $\begin{array}{l}\text { Amount of quartz variable from sample to sample but relatively } \\
\text { higher amounts of sand in upper part of some samples } \\
\text { (e.g., sample SS-4) }\end{array}$ & \\
\hline \multirow{6}{*}{$\begin{array}{l}\text { Clayey aggregates } \\
\text { from river valley }\end{array}$} & Occurs in small $(<3 \%)$ amounts in most samples & $\mathrm{SS}-5 \mathrm{~A} ; 5 \mathrm{~B}$ \\
\hline & $\begin{array}{l}\text { Variable size, from fine sand up to several millimeters } \\
\text { Generally rounded and subcircular shape }\end{array}$ & \multirow[t]{5}{*}{$\begin{array}{l}\text { SS-261 } \\
\text { (gleyed donga) }\end{array}$} \\
\hline & $\begin{array}{l}\text { Comprised of reddish clay some with inclusions of quartz silt; } \\
\text { in one case (SS-5B), diatoms are found }\end{array}$ & \\
\hline & Most are fire reddened & \\
\hline & $\begin{array}{l}\text { One large, millimeter-sized grain exhibits strong gleying } \\
\text { (SS-261); a finer clay clast contains diatoms (see above) }\end{array}$ & \\
\hline & Generally scattered but some broadly confined to layers & \\
\hline \multicolumn{3}{|l|}{ Fine clastic elements } \\
\hline \multirow[t]{5}{*}{ Calcareous ash } & Generally rare at the site, having been subjected to decalcification & $\begin{array}{l}\text { Clumps and stringers } \\
\text { of ash: SS- } 5 \mathrm{~A}\end{array}$ \\
\hline & $\begin{array}{l}\text { Where found, generally as millimeter-sized clumps or as thin } \\
(\sim 1 \text {-mm stringers) or fine }(\sim 10 \mu \mathrm{m}) \text { partially dissolved } \\
\text { crystals/grains of calcite } \\
\text { Because of dissolution, typical rhomb shapes of ashes are relatively } \\
\text { rare (except SS-5A, SS-5C) }\end{array}$ & \multirow[t]{4}{*}{$\begin{array}{l}\text { Massive, cemented } \\
\text { ash: SS-567 }\end{array}$} \\
\hline & $\begin{array}{l}\text { In sample SS-567, entire sample is cemented with calcite derived } \\
\text { from ash, which is partially recrystallized or at least masked by } \\
\text { secondary cementation }\end{array}$ & \\
\hline & $\begin{array}{l}\text { Most calcite ash is secondarily replaced with microcrystalline } \\
\text { isotropic phosphate (see below) }\end{array}$ & \\
\hline & $\begin{array}{l}\text { Found particularly above layer GR but also some traces are found } \\
\text { below GR }\end{array}$ & \\
\hline \multicolumn{3}{|l|}{ Precipitates } \\
\hline \multirow[t]{2}{*}{ Calcite } & $\begin{array}{l}\text { Generally rare but secondary cementation of ashes (e.g., SS-567) } \\
\text { With secondary cementation of ashes, bones are locally impregnated } \\
\text { with fine }(\sim 10-\mu \mathrm{m} \text { size }) \text { calcite }\end{array}$ & \multirow[t]{2}{*}{ SS-567 } \\
\hline & Tends to be more common in SS-567 and SS-569 & \\
\hline \multirow[t]{4}{*}{ Phosphate } & $\begin{array}{l}\text { Diffuse, nondescript areas of thin sections-particularly in areas } \\
\text { between more recognizable materials such as charcoal, phytoliths, } \\
\text { bone, or organic matter - which are isotropic in XPL } \\
\text { In PPL, generally pale yellow to yellow }\end{array}$ & \multirow[t]{4}{*}{$\begin{array}{l}\text { Phosphatized } \\
\text { ash: SS-4 }\end{array}$} \\
\hline & $\begin{array}{l}\text { Locally fill circular voids and spaces of spores (as seen in Schiegl } \\
\text { and Conard 2006, Fig. 2, p. 158) }\end{array}$ & \\
\hline & Phosphatized ash found in most layers and slides & \\
\hline & $\begin{array}{l}\text { Locally forms crusts on phosphatic ash layers } \\
\text { (e.g., SIB-04A; SS-5C; SS-6B) }\end{array}$ & \\
\hline Gypsum & $\begin{array}{l}\text { Occurs in many slides but seems to be restricted within the } \\
\text { upper part of the stratigraphic section and particularly certain } \\
\text { layers (e.g., LBMOD, MOD, RSp, BSp, P, OP); generally very } \\
\text { low below GR (Schiegl and Conard 2006) }\end{array}$ & $\begin{array}{l}\text { SIB-04-4B, } \\
\text { SIB-04-4C }\end{array}$ \\
\hline
\end{tabular}


Table 3 (continued)

\begin{tabular}{|c|c|c|}
\hline Component & Description and comments & Representative thin sections \\
\hline & $\begin{array}{l}\text { Overall, with globule, massive displacive shapes that range in size } \\
\text { from sand size to millimeter to centimeter size }\end{array}$ & $\begin{array}{l}\text { SIB-04-5A, } \\
\text { SIB-04-5B }\end{array}$ \\
\hline & $\begin{array}{l}\text { Globule-like accumulations are found either as displacive crystal masses or } \\
\text { Can coalesce to form bands or "layered" accumulations (e.g., SIB-04-4B) }\end{array}$ & SIB-04-6 \\
\hline & Crystal and shape within globules is variable and include: & \\
\hline & Microcrystalline type with crystal size $<5 \mu \mathrm{m}$ (SS-4) & \\
\hline & $\begin{array}{l}\text { Small }(\sim 60-80 \mu \mathrm{m}) \text {, lenticular/lozenge shape crystals (SS-5C), } \\
\text { some of which are undergoing dissolution }\end{array}$ & \\
\hline & Mosaic of large ( $\sim 0.6$ to $1.3 \mathrm{~mm})$ interlocking crystals (SIB-04A) & \\
\hline & $\begin{array}{l}\text { These commonly replace or overgrow the finer displacive } \\
\text { microcrystalline and lenticular types }\end{array}$ & \\
\hline & Euhedral to subhedral shapes & \\
\hline \multicolumn{3}{|l|}{ Miscellaneous } \\
\hline Small mammal excrements & $\begin{array}{l}\text { Rounded pellets of burnt bone and reddish fibrous material, } \\
\sim 1.5 \mathrm{~mm} \text { in diameter } \\
\text { Contain flecks of charcoal, quartz silt, and slightly coarser angular } \\
\text { splinters of bone in a somewhat porous matrix of finely divided } \\
\text { organic matter that is brown in color }\end{array}$ & SS-6A \\
\hline Eggshell & $\begin{array}{l}\text { One burnt tablet-shaped fragment from SS- } 569 \\
\text { Isolated and surrounded by ashy but partially decalcified matrix }\end{array}$ & SS-569 \\
\hline \multirow[t]{2}{*}{ Char } & $\begin{array}{l}\text { Occurs as grains in certain samples } \\
\text { In SS-5C, occurs as vesicular, porous black grain } \sim 1.2 \mathrm{~mm} \text { across, } \\
\text { with some fine cracks }\end{array}$ & $\begin{array}{l}\text { SS-4; SS-5B; } \\
\text { SS-5C }\end{array}$ \\
\hline & $\begin{array}{l}\text { In SS-5C, occurs as broken finely fissured angular blocks, } \\
\sim 500-750 \mu \mathrm{m} \text { across }\end{array}$ & \\
\hline
\end{tabular}

of quartz, although some mica and heavy minerals were found within this size class. Clay occurs in several samples but as aggregates usually within the range of fine sand (>62 $\mu \mathrm{m})$ to several millimeters in diameter and containing inclusions of silt quartz. They are typically rounded and subcircular, occurring throughout the matrix as individual grains but also exhibiting bedding in certain instances. One large millimeter-sized clay aggregate exhibits gleying (in sample SS-261). This, along with the presence of an aggregate of finer clay with diatom inclusions, suggests that the aggregates are derived from the local Tongati river valley. The clay aggregates also resemble clay aggregates found in a sample from a "Daga floor." This is an Iron Age trampled floor constructed from clay brought to the cave from the Tongati River. Many of the aggregates from the Middle Stone Age (MSA) layers appear fire-reddened.

Organic constituents by organic petrology Although both woody and herbaceous charcoal was identified using standard micromorphological techniques, numerous submillimeter constituents are present in the thin sections and defy simple identification with standard methods. Organic petrographic microscopy aided in identifying these constit- uents and emphasized the complexity and variety of combusted material present in archaeological features (Fig. 4).

Organic petrography confirmed that a major organic constituent of the sediment at Sibudu is charcoal, both woody and herbaceous. This material can be classified as "fusinite" and "inertodetrinite" (fusinite is fragments that are smaller than $20 \mu \mathrm{m})$. Both are products of incomplete burning, or charring, of lignin- or cellulosecontaining tissues (Taylor et al. 1998). Most of the identifiable charred plant material was derived from herbaceous plants, with identifiable tissues from leaves, stems, and roots being the most numerous. Reflectivity measurements on the charcoal particles have shown that the reflectance mean values (Ro) range from $1.27 \%$ to $1.40 \%$.

Two types of amorphous organic combustion remains were identified in samples from Sibudu: a type with a typically vesicular texture and a type with a cracked texture. The first type was found as isolated bodies, subrounded with a diameter of $10 \mu \mathrm{m}$ to $1 \mathrm{~mm}$, and they exhibited no evidence of cell structure. Bubbles or vesicles give the bodies a highly porous nature, and they are often thin walled. The microstructure of these 

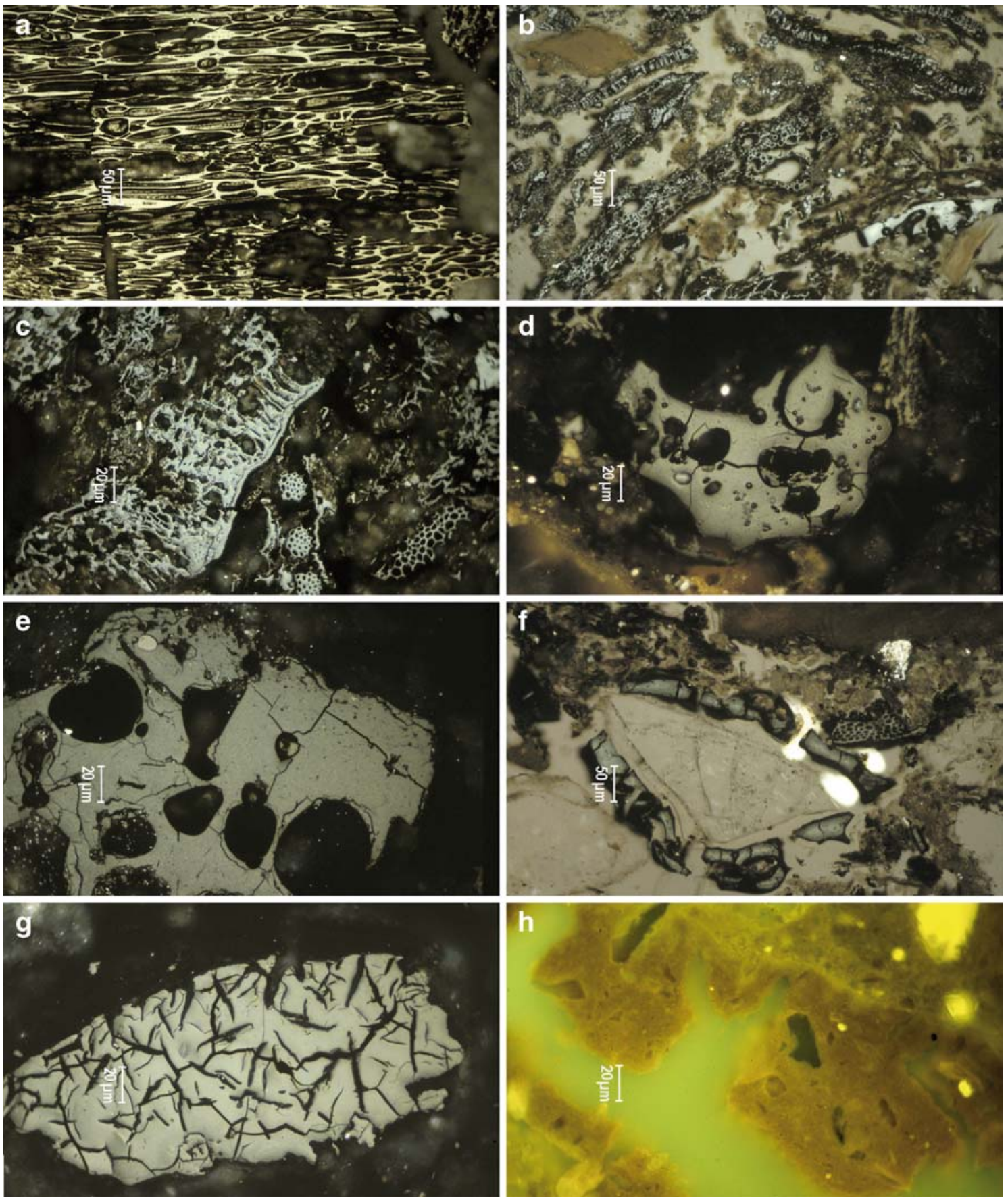

Fig. 4 a Charcoal: high-reflecting wood-derived fusinite. Incident light, oil immersion. b Charcoal: fusinitized herbaceous tissues (medium reflecting) and high-reflecting char (bottom right). Incident light, oil immersion. c Charcoal: leaf-derived fusinite, medium reflecting. Incident light, oil immersion. d Fat-derived char showing characteristic random pore distribution. Note the droplet-shaped char in the upper part of the particle. Incident light, oil immersion. e Char

homogenous or finely heterogeneous isotropic particles and their droplet-shaped occurrence suggest that these bodies were originally fluid and that they underwent a degassing process but have since hardened. These bodies with charcoal inclusions (white fragment $S$ and inertodetrinite Id). Incident light, oil immersion. f Thin coating of fat-derived char surrounding a quartz grain. Incident light, oil immersion. g Secretinite showing characteristic internal notches and high reflectivity. Incident light, oil immersion. h Brown-yellow fluorescing resinite with mineral inclusions. Incident light, fluorescent mode, oil immersion

resemble char and are probably derived from the burning of flesh or animal fat. The mean reflectance values range from $0.91 \%$ to $2.20 \%$, correlating well with organic constituents that form by charring (such as fusinite), 
which are characterized by a high reflectivity (Taylor et al. 1998).

The second type of amorphous bodies, those with a cracked structure, can exhibit an oval or rounded form, although forms with an irregular outline were noted. They are typically homogenous, isotropic, and 10 to $450 \mu \mathrm{m}$ in diameter. Their mean reflectance values range from $0.45 \%$ to $1.96 \%$. These types of bodies are known to the field of organic petrography as secretinite (ICCP 2001), although the origin of this material is not totally clear. It is possibly a by-product of burning resin or gum, derived from trees or possibly from the burning of seeds.

Nonburnt organic substances were identified through organic petrology, including resinite, a constituent derived from plant materials, such as resin, or wax (Taylor et al. 1998). The identification of unburnt resin supports the hypothesis that the secretinite could be derived from burnt resin.

Microfacies The sediments at Sibudu are complex and, as mentioned above, it is in some cases difficult to trace an individual stratigraphic unit from one profile of the trench across to another. Such small-scale changes in lithology reflect different human activities that took place in discrete places within the cave space. Thus, in order to try to study the sediments effectively and to characterize and interpret them, we have opted to employ the concept of microfacies.

Microfacies, as originally conceptualized in geology decades ago and as currently understood, makes use of petrographic and palaeontological observations in thin sections, peels, polished blocks, and rock samples to describe and infer past sedimentary environments (Flügel 2004); it has been used particularly in carbonate petrology. Recently, Courty (2001) applied the concept to geoarchaeological settings, particularly those characterized by anthropogenic inputs and modifications, such as those in Near Eastern tell sites and prehistoric cave deposits. By their very nature, such archaeological deposits reflect past human activities, which include depositional and postdepositional modifications, where lithological changes, like at Sibudu, are common over short horizontal (and vertical) distances. As a consequence, Courty expanded the range of stratigraphic observation over a continuum from thin section to field in order to keep track of and account for different human activities, which can take place in different parts of the same site at the same time; these activities leave different types of deposits and fabrics.

At Sibudu, fine stratigraphic subdivisions were achieved during excavation (Wadley and Jacobs 2004, 2006) and represent microfacies as championed by Courty (2001). In this paper, however, we use microfacies more in the sense as it was originally conceived: lithological changes within an individual thin section. Since it is impossible to divorce micromorphological observations from those in the field, we continually attempt to relate what we see in thin section to what was observed in the field, at both the site and regional level.

Below, we present an inventory of microfacies as identified through microscopic examination of thin sections. The brief descriptions are included with a representative microphotograph of each microfacies type (Fig. 5). A schematic cartoon illustrating the organization of the different components and a list of which samples contain the specific microfacies are included within Table 4, along with an interpretation of the formation processes associated with each microfacies, as discussed below.

1. Microfacies type 1, phosphatic - this massive microfacies has a fluffy microaggregated aspect of yellow apatitic material. It is comprised of layered to very finely laminated grains, including possibly clay. It contains phytoliths and woody tissues, with inclusions of quartz silt and clay papules. It exhibits a possible phosphatic crust.

2. Microfacies type 2, laminated organic matter-this type consists of finely laminated fibrous organic material, which varies in color from black (charred) to reddened (humified?). Inclusions of charcoal, burnt bone, lithics, éboulis, aggregated sediment from the river valley (which can be fire-reddened), and phosphatic grains (e.g., coprolites, reworked phosphatic crusts) can also occur. These elements can be commonly organized in variable proportions into stringers (thin lenses).

Two subtypes also occur:

(a) Microfacies type $2 \mathrm{~A}$, laminated organic matter with charcoal-this subtype is the same as microfacies 2 except that it contains larger clasts of éboulis, bone (mostly burnt), lithics, woody charcoal, and rock fragments. Burnt bone and woody charcoal commonly appear crushed and form stringers. Larger clasts occasionally are impressed into the underlying substrate/deposits.

(b) Microfacies type $2 B$, laminated organic matter with phytoliths - this subtype is comprised of finely laminated fibrous organic matter and phytoliths, along with burnt bone that has been heated to varying degrees; crushed burnt bone forms surfaces and stringers. In addition, erratic clasts of river valley sediment are present, some of which are burned. In some instances, calcite ash is present but is being dissolved. In sample SS-6A, gypsum occurs as lozenge shapes, and needles of gypsum formed on a sandstone clast are $\sim 1.2 \mathrm{~mm}$ long.

3. Microfacies type 3, massive charcoal-this microfacies occurs in layers and is composed of massive charcoal; 
in some cases, it is associated with rubefied substrates. Internal organization of material is chaotic. In certain instances, it occurs with calcareous ashes when they are not phosphatized.

4. Microfacies type 4, laminated phytoliths-this is a distinctive and striking microfacies consisting of microlaminated phytoliths with little or virtually no mineral or organic matrix; pockets of phosphate and some burnt bone occur. Phytoliths are of various types.

(a) Microfacies type $4 A$-in this subtype, the phytoliths are nonlaminated and contain inclusions of rock fragments, charcoal, and crushed bone; burnt river valley sediment also occurs.
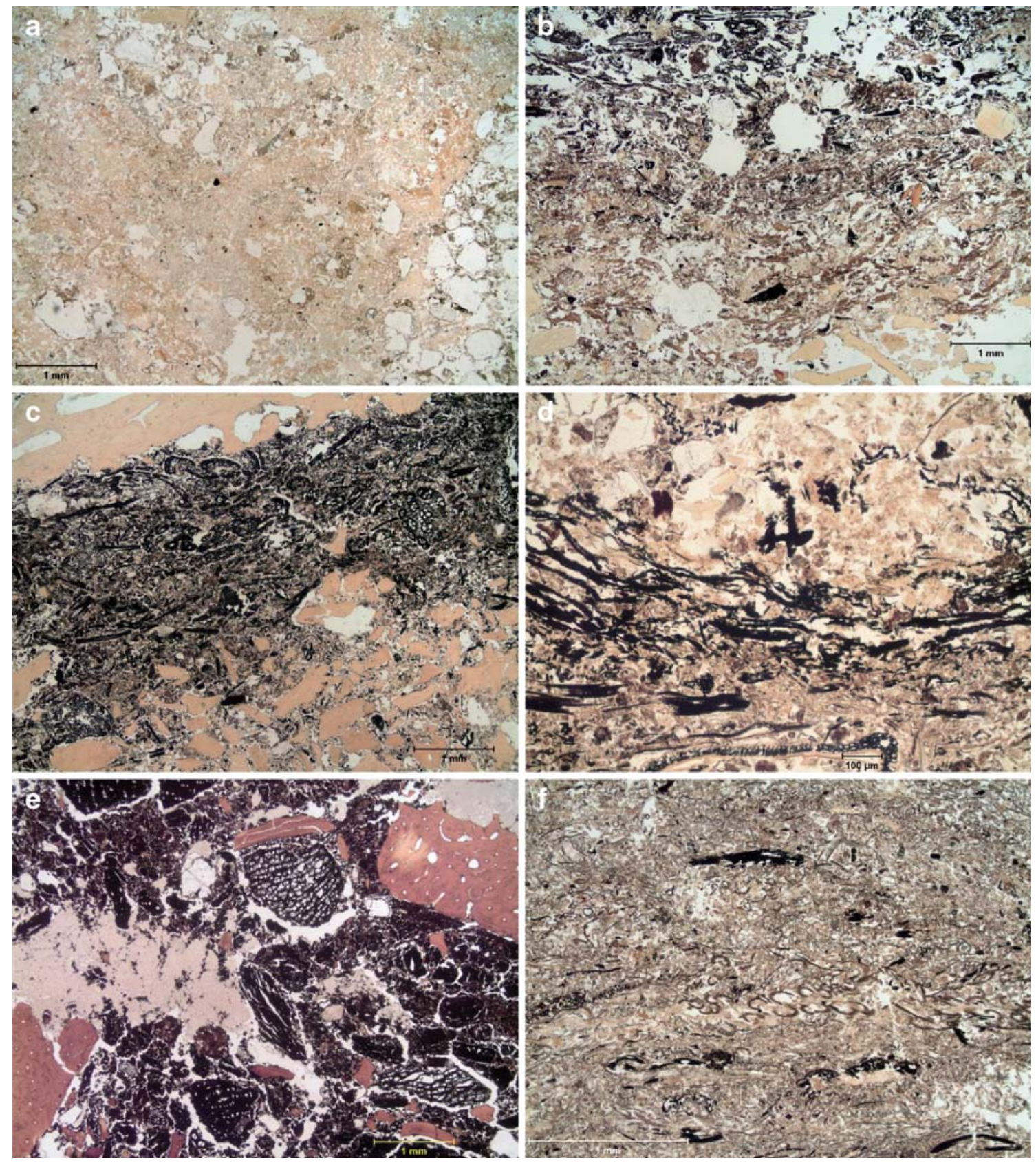

Fig. 5 Microphotographs of microfacies types. a Microfacies type 1, phosphatic. b Microfacies type 2, laminated organic matter. Note that the top of this figure contains some portions of microfacies type 3. c Microfacies type 2A, laminated with charcoal. Note the crushed bone at the base of this microphotograph. d Microfacies laminated type 2B with phytoliths. e Microfacies type 3, massive charcoal. (f) Microfacies type 4, laminated phytoliths. g Microfacies type 4A, nonlaminated phyto-

liths. h Microfacies type 5, homogenous anthropogenic components. Note the presence of microfacies type $2 \mathrm{~B}$ at the base of the microphotograph. i Microfacies type 6, phosphatic and calcareous ash. Note the calcite rhombs typically associated with plant ash. Microphotograph taken in cross-polarized light. j Microfacies type 6A. k Microfacies type 7, massive sand. I Microfacies type 8, massive, compact, very little void space 

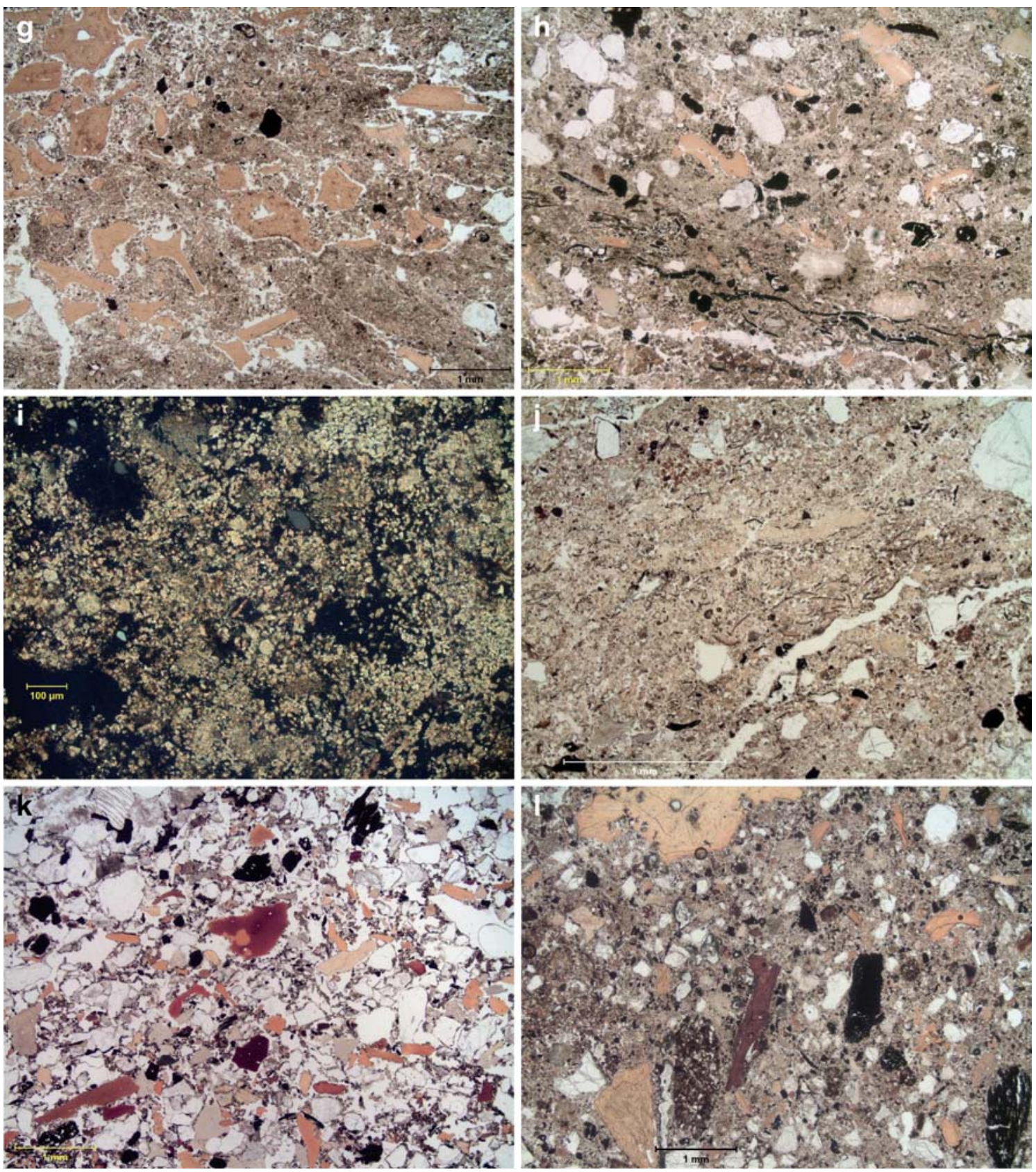

Fig. 5 (continued)

5. Microfacies type 5, homogeneous anthropogenic components - this homogeneous microfacies is composed of bone, phosphate, and charcoal, with sand- and siltsized quartz grains. These components are completely mixed, without any layering or concentrations of individual elements. Particles range from granule size to silt size. Phytoliths occur throughout and are an important but not dominant component.

(a) Microfacies type 5A-same as type 5, but without phytoliths.
6. Microfacies type 6, phosphatic and calcareous ashthis is another distinct microfacies. It is rich in phosphatic and calcareous ash accompanied by active dissolution of calcite; gypsum crystals occur throughout. Brownish phosphatized plant material-including phosphate pseudomorphs of ashed plant materialsoccurs, as well as some phytoliths. A phosphatic crust is present on top of the microfacies in SS-5C.

(a) Microfacies type $6 A$-type $6 \mathrm{~A}$ is similar to 6 , but ash is more diagenetically altered to the extent that 
Table 4 Microfacies types identified in thin sections from Sibudu with a schematic representation of the facies, a list of thin sections where present and the proposed interpretation of the microfacies type

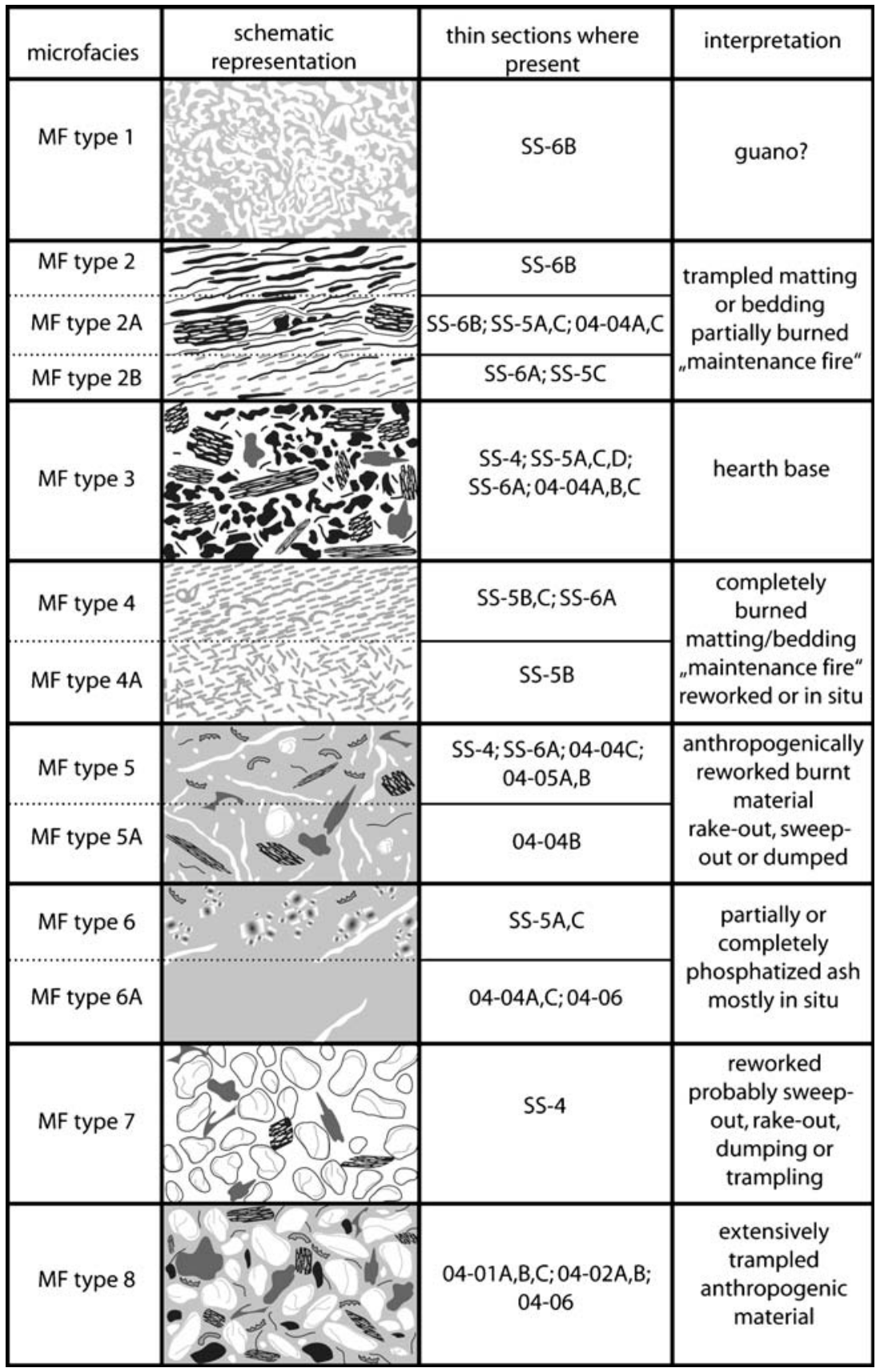

calcite is no longer visible and the sediment is completely isotropic. Phosphatic crusts may be present.

7. Microfacies type 7, massive sand-this is a massive sandy microfacies that includes sand-size pieces of angular burnt bone fragments and pieces of charcoal. The microstructure is quite granular and open.

8. Microfacies type 8, massive, compact, and very little void space-this is a homogeneous mixture of most major components. The bone is fairly angular and fibrous and woody types of charcoal are present. Large fragments of river valley sediment are also present. The fine matrix is mostly phosphatic.

\section{Discussion}

Since the majority of components at Sibudu are anthropogenic and because the structuring of these components - as interpreted from the different microfacies - results directly 
from humans acting as depositional agents, it is possible to determine the different human activities occurring at the site during single and repeated occupations. By differentiating between the structural organization of different microfacies (Table 4), it is possible to distinguish between two different types of combustion features.

The first type of combustion feature, referred to here as hearths, represent the intentional transport of wood or plant material to the cave for the purpose of burning that material to produce light or heat. The actual function of these hearths is not discernable, and is probably not easily classified-cooking hearth, heating hearth, or a hearth for light or protection. These hearths could have served any one of these purposes and most likely served several of these purposes at any one time during their use.

The second type of combustion feature- the burning of bedding (Macphail et al. 1997) - may represent a distinct behavioral practice associated with fire. In this paper, we chose to use the term "bedding" rather than "mats" to refer to the laminated fibrous material found in thin section since "mats" may imply a woven material, which does not appear to be the case at Sibudu. By using "bedding," we do not intend to imply a specific functionality of this material (i.e., sleeping). Rather, we see the plant material as a general surface preparation that could have been used for various purposes (sleeping, sitting, etc.). The repetitive nature of the burnt bedding in the sequence and the overwhelming presence of anthropogenic components and processes present at Sibudu rule out the possibility that these fires were started naturally, such as by lightning strikes. One possibility is that the beds were burned as a result of coming into close contact with adjacent hearths. While it seems very likely that some singeing of the beds occurred during occupation and use of adjacent hearths, it seems unlikely that the complete ashing of the upper portion of the beds occurred accidentally. The repetition of burnt bedding at the site also argues for intentional, rather than accidental, burning.

Whereas the construction of hearths represents burning of material with the goal of acquiring fire, either for cooking, heating, or light, the burning of bedding appears to be associated with the maintenance of the site and represents a change in their functionality: while initially useful as bedding - enough so that they were repeatedly managed by adding more plant material over time - their usefulness for the inhabitants of Sibudu cave changed so that their destruction through fire was deemed necessary. The actual intent behind the burning of the bedding is most likely impossible to infer; however, it seems reasonable that hygienic concerns may have played a role, as older beds may have attracted vermin or were seen as dirty after repeated use. In this sense, we would refer to the burning of bedding as "maintenance fires," to distinguish these combustion events from the hearths identified in this study. Cleaning of the site also was inferred at Sibudu by Cain's (2005) study of burnt and fragmented bone incorporated in ash dumps.

A genetic interpretation of microfacies types at Sibudu

Microfacies 1, phosphatic, is found only in one slide (SS$6 \mathrm{~B}$ ) and consists of fluffy phosphatic material, with a crust formed on its upper surface (Fig. 5a). It contains several inclusions, such as wood fragments, phytoliths, and some clay papules. The structure of the phosphatic material suggests that a portion of this microfacies could be derived from guano, although the inclusion of phytoliths and woody fibers may hint at an ash component. Even if present, the ash has long since been phosphatized due to the presence of guano. The phosphatic crust indicates that the top of this layer was exposed on the surface for a period of time (possibly weeks to years), allowing for phosphatization to occur.

Microfacies 2, laminated organic matter, and its various subfacies types (type $2 A$, laminated with charcoal and laminated type $2 B$ with phytoliths) are one of the more common microfacies types identified at Sibudu (Fig. 5b-d). It is found in almost every sample collected within the finely laminated sequence above approximately layer YA2. The unifying component of microfacies 2 and its subtypes is laminated fibrous organic material-usually burned but not always - that in certain cases exhibits signs of humification. Some of this material certainly corresponds to the herbaceous fusinite identified by organic petrographic analysis. What differentiates the subfacies of microfacies type 2 is the inclusion of other components within the laminated fibrous fabric.

Laminated type $2 A$ with charcoal, for example, usually contains centimeter-sized pieces of woody charcoal that often appear crushed, forming stringers along a surface as defined by the microlaminated organic fibers of the matrix (Fig. 5c). This subfacies may also contain larger clasts of éboulis, pieces of chipped stone, bone (typically burned), and aggregates of river valley sediment. Like the pieces of woody charcoal, these larger components are often organized parallel to the direction of bedding as defined by the fibrous organic material. In some cases, particularly with less robust components, such as burnt bone and river valley sediment, the inclusions appear crushed and are often spread out as stringers along a surface. Some larger components appear to deform the underlying structure of laminated organic fibers, as if they had been impressed into the underlying substrate.

Laminated type $2 B$ with phytoliths has the same characteristics as laminated type 2A with charcoal (Fig. 5d). This subfacies, however, contains phytoliths, often oriented 
parallel to the bedding direction. Plant ash, although partially dissolved, has been found in this microfacies based on the identification of calcite rhombs (Courty et al. 1989; Brochier and Thinon 2003; Canti 2003). The bulk of this microfacies consists of laminated fibrous organic matter that does not have a woody structure (K. Deckers 2008, personal communication). Because of its long fibrous nature, it seems that this material consists of herbaceous plants, possibly some type of sedge, reed, or grass. There is no evidence to suggest that this plant would have grown naturally in the rock shelter, and the presence of clay aggregates derived from the river valley found in association with the laminated plant fibers implies that the grass or reed was transported to the cave from the nearby Tongati River by the shelter's inhabitants.

The compact and laminated structure of the organic fibers in this microfacies also suggests that, once brought to the cave, the grass or reed was subjected to compaction, most likely through trampling. Further evidence supporting the interpretation of trampling is seen in the stringers of charcoal, clay aggregates, and burnt bone that define horizontal and subhorizontal surfaces on top of and within the laminated organic fibrous material. Pieces of éboulis and lithic fragments also define surfaces within the microfacies. The fact that this grass or reed was transported to the cave by humans and that once there it was influenced by human trampling suggests that this microfacies represents a type of constructed bedding. If this is the case, then Sibudu contains the oldest evidence for constructed bedding, significantly older than that reported at the openair site of Ohalo in Israel (Nadel et al. 2004).

Often found directly above microfacies type 2 (typically subfacies laminated type 2B) is microfacies type 4, laminated phytoliths (because of this association, microfacies type 3, massive charcoal is discussed further below). This microfacies consists almost exclusively of phytoliths that are laminated (Fig. 5f). In some instances, pockets of phosphate are found in the microfacies, as well as burned, possibly calcined, bone fragments.

Since this microfacies is almost exclusively found directly above microfacies laminated type 2B (laminated organic matter with phytoliths), which also contains phytoliths in addition to stringers of burnt fibrous organic material, it seems that this microfacies is genetically linked to microfacies type 2 and its submicrofacies. The laminated organization of the phytoliths mirrors the laminated structure of the underlying fibrous organic material and implies that this microfacies represents a similar depositional process as determined for microfacies type 2 . What seems a likely and reasonable scenario is that the original organic matter of this laminated layer of sedges, grass, or reeds was completely combusted, resulting in total ashing of the organic material. The calcitic ash in this microfacies was transformed through phosphatization, as evidenced by the presence of a few remnant pockets of phosphate in this microfacies. The fact that large crystals of gypsum often form directly below these phytolith layers provides suggestive evidence for the downward leaching of $\mathrm{CO}_{3}{ }^{-}$or P-rich solutions. The association between microfacies 2 and 4 suggests that the sedges, grass, or reeds that were brought into the cave for bedding were usually burned and probably by humans when they no longer used the bedding. This observation explains the sequence seen in samples SS-6 and SS-5 of laminated nonburnt fibrous organic material grading into laminated burnt fibrous organic material with phytoliths (microfacies laminated type $2 \mathrm{~B}$ ); the sequence is finally capped by a layer of laminated phytoliths.

It seems that the fire temperatures were high enough to ash the uppermost portion of the bedding. Below the surface, however, temperatures were lower, resulting in only charring of the organic material. The lowermost sections of these layers appear to not have been significantly influenced by the overlying burning event (cf. Sievers and Wadley 2008). Together, this evidence shows that not only were the occupants of Sibudu bringing grass or reeds into the cave-likely for the construction of bedding - but they were periodically burning them, possibly as a means to remove pests or insects that had colonized the beds. (Smoldering goat dung and organic matter can be observed in many parts of the Middle East, including Hayonim, where tick removal is one of the important objectives; P. Goldberg 1992, personal observation.) The micromorphological evidence supports ideas put forth by Sievers and Wadley (2008) and Sievers (2006) who believe that a high percentage of charred sedge seeds found in the Sibudu sediments provides indirect evidence for the presence of sedge bedding.

Subtype microfacies type $4 A$ consists almost exclusively of phytoliths (Fig. 5g), although they are not laminated. This microfacies can contain inclusions of éboulis and debitage, charcoal, burnt aggregates of river valley clays, and crushed bone. It is reasonable to assume that this phytolith-rich microfacies was produced in the same manner as microfacies type 4; however, the nonlaminated organization and the inclusion of larger-sized components, suggests that this layer represents reworking of microfacies type 4-possibly the result of sweeping or trampling of previously burnt bedding.

Microfacies type 3 (massive charcoal) provides a different type of evidence for combustion-related activities at Sibudu (Fig. 5e). This facies consists of layers of massive woody charcoal, some of which appear to be dicotyledonous (K. Deckers 2008, personal communication), with some finely comminuted fibrous charcoal. This material, like that from microfacies type 2, corresponds to the 
herbaceous and woody fusinite identified through organic petrographic analysis. Some of the more amorphous blackcolored material visible in this microfacies can also be identified as secretinite, burnt seeds or resin/plant gum, and fat-derived char. The internal organization of these components is chaotic, standing in stark contrast to the finely laminated organization of material found in microfacies type 2. Typically, this microfacies is found in association with an underlying rubefied substrate (see, for instance, samples SS-6B and SS-5A). Where the surface of this microfacies unit has been preserved and not removed by erosion (as is the case in sample SS-4), calcareous ashes can be found: they are partially dissolving but still exhibit the classic rhomb form (e.g., sample SS-5A). An example of microfacies type 3 in sample SS-6B does not exhibit any calcareous ashes, but directly over the massive charcoal is a fine layer of phosphatic material, which hints at the former presence of ashes that have since been diagenetically altered. The overall structure of microfacies type 3 and the associated rubefication and overlying ashes show that these features represent intact combustion features more in line with classic hearths.

Microfacies type 5, homogeneous anthropogenic components, in contrast to the previously discussed microfacies, is homogeneous and not structured (Fig. 5h). It is composed of phosphate, bone, and charcoal, with inclusions of sandand silt-sized grains of quartz. All of the components are completely mixed, and no obvious bedding or concentration of components is evident. Phytoliths are an important although not a dominant component of the microfacies. Microfacies type $5 B$ is identical to microfacies type 5, except that type $5 \mathrm{~B}$ lacks phytoliths. The phosphatic nature of microfacies types 5 and $5 \mathrm{~B}$ suggests that they represent diagenetically altered plant ash. This is supported by the presence of phytoliths in microfacies type 5: the absence of phytoliths in microfacies type $5 B$ may indicate that a different fuel was used to produce the ash. The massive structuring of this microfacies and the chaotic organization of the larger components within the finer phosphatic matrix show that, although this microfacies is associated with combustion-related activities, it is not in its primary location. Rather, it most likely represents redeposited ash, either as the result of sweeping or possibly dumping.

Microfacies type 6, phosphatic and calcareous ash, is similar to microfacies type 5 in that it consists of mostly phosphatized material. Unlike microfacies type 5, it does not contain the same type of inclusions but rather contains calcareous ash, which is actively being dissolved (Fig. 5i). Gypsum crystal formation is also present. Brown-colored phosphatized plant matter, often in the form of phosphate pseudomorphs of ashed plants, is found. Phytoliths are also present. Microfacies type $6 \mathrm{~A}$ is similar to microfacies type 6 , but it appears more diagenetically altered, with the ash being completely phosphatized (Fig. 5j). For both microfacies, phosphatic crusts may be present (see, for instance, sample SS-5C), indicating a period of surface exposure. Because of the extensive diagenesis and gypsum formation, it is difficult to determine the origin of this ash, although in some instances it appears at least partially reworked, either through sweeping or raking out of combustion features.

Microfacies type 7, massive sand, contains the highest proportion of mineral components (quartz sand) of all the identified microfacies (Fig. 5k). It also contains a significant proportion of anthropogenically derived components, including sand-sized angular fragments of burnt bone and charcoal. The organization of the components in this microfacies is granular and open, suggesting redeposition, through raking out, sweeping, or possibly trampling.

Microfacies type 8, massive, compact, very little void space, is a massive homogenous mixture of most components identified at Sibudu and is the dominant microfacies of samples collected from the lowermost homogeneous Howiesons Poort and pre-Howiesons Poort layers (Fig. 51). The fine matrix is mostly phosphatic, probably representing phosphatized ash. Angular bone fragments are common, as are pieces of charcoal, both fibrous and woody. Large aggregates of clay derived from the Tongati River are also present (some of which are burned). The structure of this microfacies is very compact, with very little void space. This structure rules out the possibility that the homogeneous nature of this microfacies is a result of bioturbation: the total lack of biogalleries and voids, the ubiquity of anthropogenically derived material forming the vast majority of the components of this microfacies, and the compactness of the microfacies all suggest that this layer was formed by human trampling. This trampling reworked any combustion-related features, redistributing the components, and formed a compact homogeneous unit of mostly burnt material (ash, charcoal, burnt bone, etc.).

Activity-based interpretation of a selected sample

As a means to summarize visually some of the above discussion, we present here some illustrations that characterize an activity-based interpretation of microfacies sequences from this study. In this section, we discuss in greater detail a selected sample, representing the most typical and important microfacies sequences at Sibudu. Limitations of space preclude a complete discussion of all the sampled deposits at Sibudu but are carefully summarized in the included figures (Figs. 6, 7, 8, and 9)

Sample SS-6 ( $A$ and $B$ ) collected from the B4/B5 line (east face of B5) contains layers $\mathrm{Ma} / \mathrm{BO}, \mathrm{BM}$ and Pox (Table 2). The lowermost section of sample 6B is a massive fluffy layer of phosphatic material (MF type 1) that contains authigenic gypsum, mostly located near the top of this layer 
a

Sample SS-6A-B

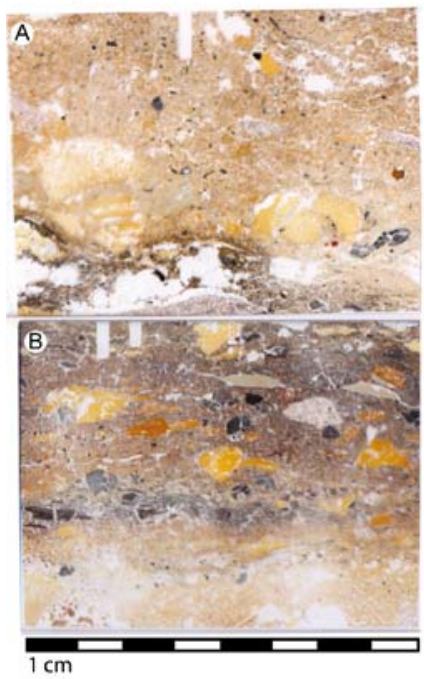

anthropogenic

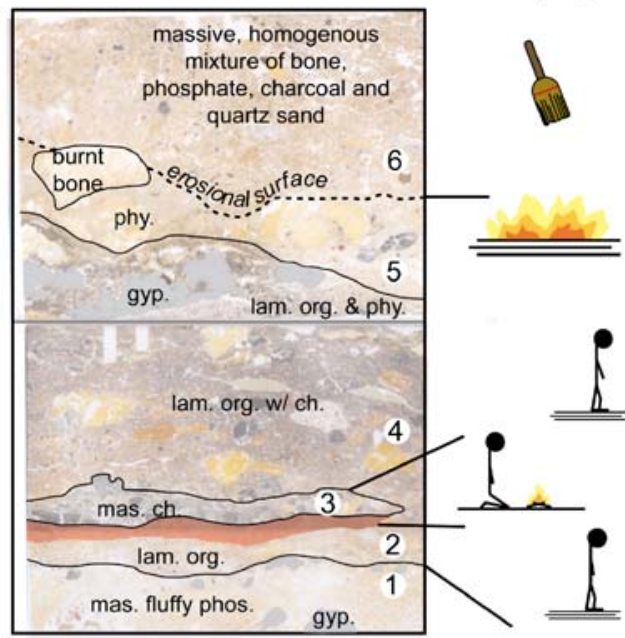

geogenic/biogenic

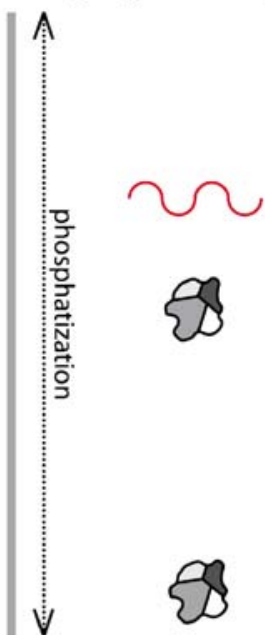

b

Legend

burnt bedding

„maintenance fire“

in situ hearth

trampled grass

matting

redeposited material (sweeping, rake out, etc.)

trampling

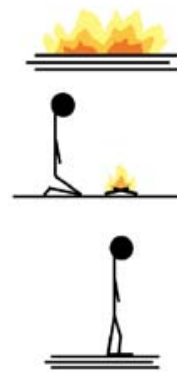

$B$ pellets erosion

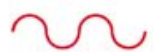

presence of faecal

rubefied substrate
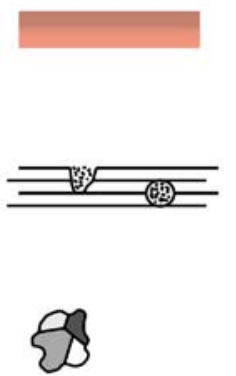

gypsum

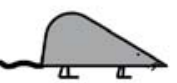

Fig. 6 a Sample SS-6A-B. (1) Massive fluffy phosphate (MF type phosphatic type 1), with localized splotches of authigenic gypsum formation, particularly at the top of the layer. This layer may represent phosphatized ash; however, the structure and homogenous nature of the phosphate suggest that this may be guano from birds or bats. (2) Laminated fibrous organic material (MF type 2). This probably represents trampled bedding. (3) Massive charcoal, with chaotic structuring (MF type 3). A yellowish layer above this massive charcoal probably is phosphatized ash. This, with the presence of a rubefied zone below the massive charcoal layer, supports the interpretation that this is an in situ hearth. (4) Laminated fibrous organic material, similar to (2) but containing large pieces of charcoal (MF type 2A). Large pieces of burnt bone are present and crushed in situ, forming stringers. This, plus the laminated fibrous material, suggests that this layer represents bedding or a series of beds. This layer grades into (5), which is a layer of laminated phytoliths (MF type 4). This suggests that the bedding was burned in situ. The phytolith layer is eroded at its surface. (6) overlies the erosional surface on (5) and consists of a massive mixture of phosphate, angular burnt bone sand, and quartz grains (MF type 5). This layer is probably a mixture of phosphatized ash with other components, the organization of which suggests reworking, probably by sweeping or raking out of an adjacent hearth or combustion feature. b Legend indicated the symbols used for the anthropogenic and geogenic interpretation of formation processes 
Sample SS-5A-B
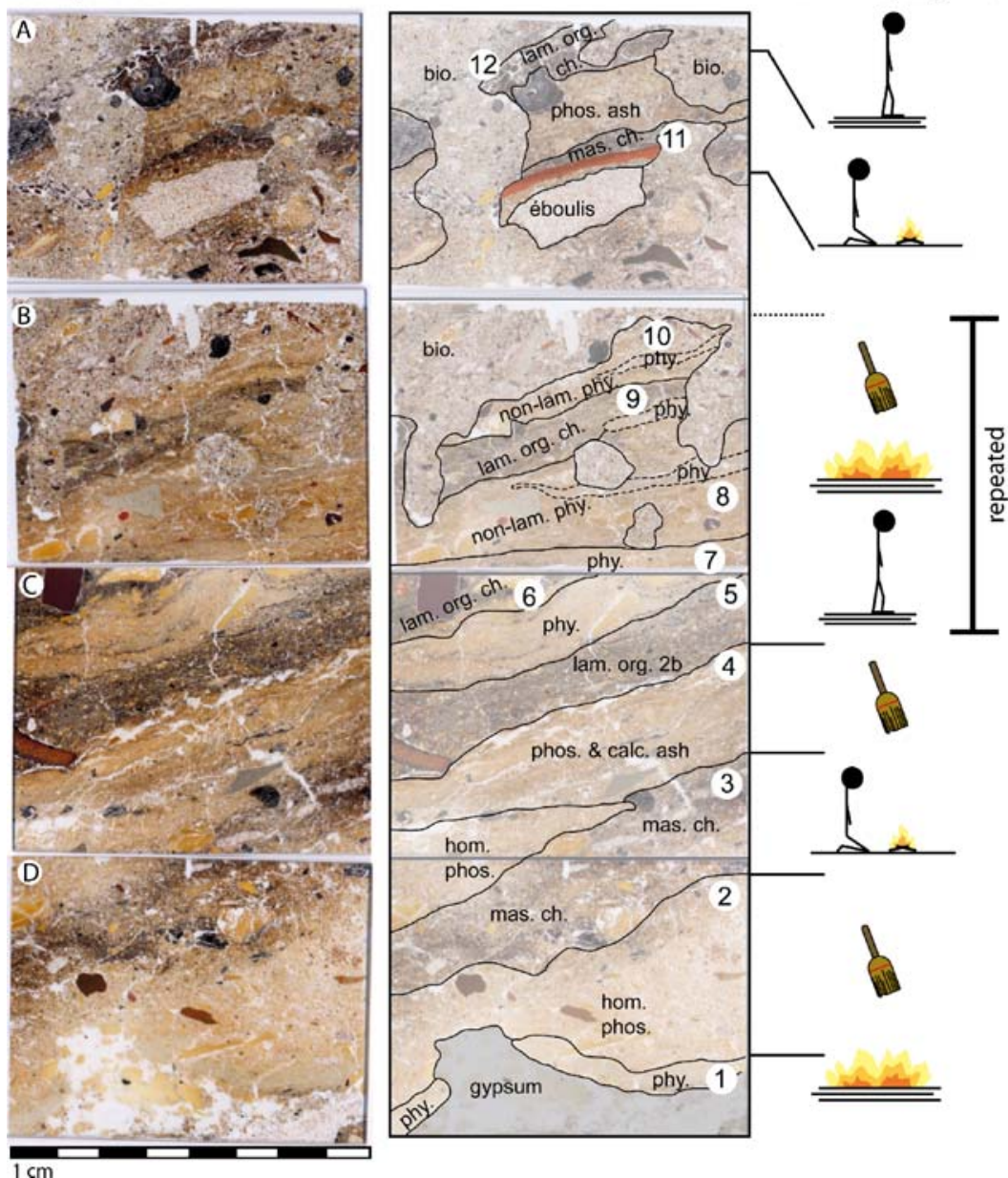

\section{geogenic/biogenic}

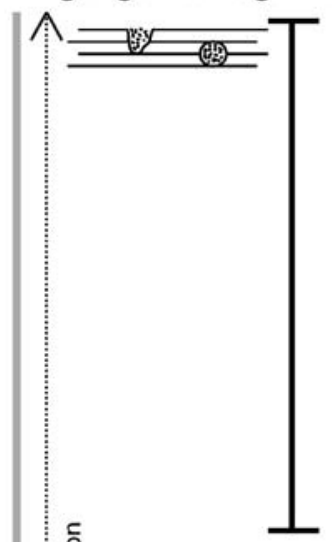

Fig. 7 Sample SS-5A-D. (1) Extensive authigenic gypsum formation that breaks through the overlying laminated phytolith layer (MF type 4). This sequence probably represents in situ burning of trampled bedding. (2) Homogenous phosphatic material (MF type 5) containing burnt bone, fire-altered river valley sediment, and phytoliths. The phosphatic material is probably phosphatized ash. The chaotic and open structure of the components suggests that this material was reworked or redeposited (sweeping/raking out or dumping). (3) Massive chaotically structured charcoal (MF type 3 ). The components and structure of this layer suggest an in situ hearth. However, portions have been reworked, possibly by trampling. (4) Consists of two layers, one of which pinches out. Based on the components and structure of these layers, they most likely represent sweep or rake out of ash from adjacent hearths. The lowermost layer that pinches out is extensively phosphatized (MF type 5), whereas the uppermost layer contains evidence of its original calcareous nature, with calcitic ash rhombs still present (MF type 6). (5) Fibrous material, some of which is partially burned (MF type 2B), grading into an overlying layer of laminated phytoliths (MF type 4). This sequence probably represents trampled bedding, which was ultimately burned. (6) Laminated fibrous organic

(Fig. 6). The upper contact of this phosphatic unit is marked by the formation of a phosphatic crust. Although this layer possibly consists of phosphatized ash, the fluffy structure of the phosphate is more reminiscent of guano (Karkanas and Goldberg 2009). The presence of authigenic gypsum within phosphate-rich guano suggests that the presence of gypsum material and containing larger pieces of charcoal and bone (MF type 2A). (7) Laminated phytoliths (MF type 4): this sequence again represents trampled bedding that was burned in situ. (8) Nonlaminated phytoliths mixed with phosphatic material (MF type 4a). This is probably reworked ashy material, possibly representing sweep out or rake out of an adjacent combustion feature. The high number of phytoliths may suggest that this is reworked material from a grass bedding. (9) Laminated fibrous organic layer (MF type 2A) and is marked on its surface by a possible erosional event. Probably represents bedding. (10) Nonlaminated phytoliths (MF type 4a), representing sweep out or rake out of an adjacent combustion feature, possibly a burnt bedding. (11) The rest of the sequence is heavily modified by bioturbation; however, the remnants of a massive charcoal layer (MF type 3), with a rubefied base and overlying ash, can be identified in sample $5 \mathrm{~A}$ as an in situ hearth. (12) On top of the ash are the remnants of laminated organic material (MF type 2A), representing a trampled grass bedding. Throughout the sequence, phosphatization has strongly effected the preservation of calcitic material, most notably ash. There are only a few zones where ash has not been completely altered

is at least partially a result of the diagenetic alteration of guano (Shahack-Gross et al. 2004). The presence of a diagenetically produced phosphatic crust is the result of this layer being exposed to the surface for a period of time. Directly above the phosphatic crust is a layer of finely laminated fibrous organic matter that does not contain large 


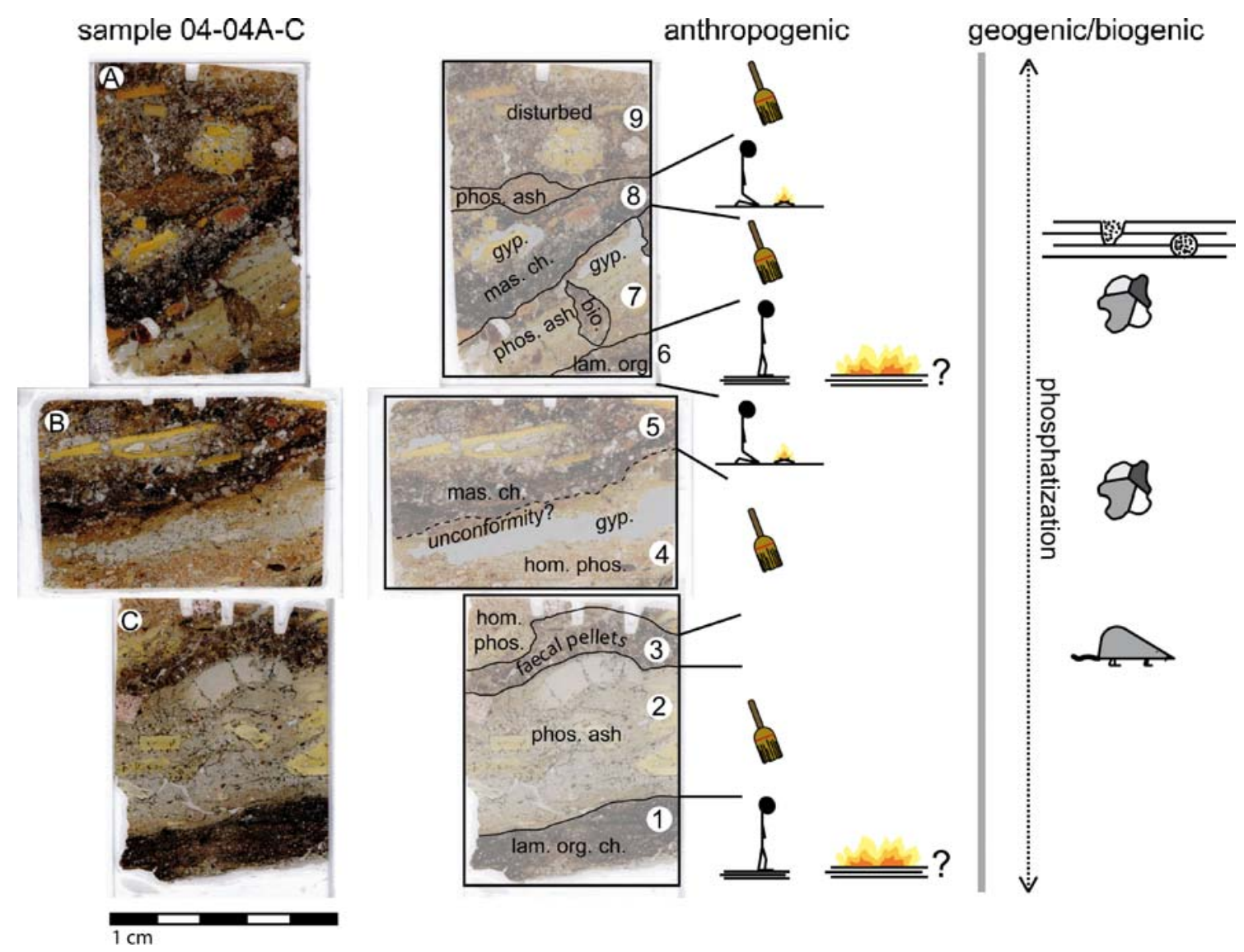

Fig. 8 Sample 04-04A-C. (1) Laminated organic material with some pieces of charcoal (MF type 2A). The laminated fibrous material is partially charred. This probably represents trampled bedding. It could have been burned in situ, although this layer lacks the accompanying overlying phytolith layer found in other samples (see samples 4,5 , and 6). (2) Massive layer of phosphatized material (probably ash) which contains phytoliths, calcined bones, and fire-altered clasts of river valley sediment (MF type 6A). The reddened river valley sediment gives the light-colored phosphatized ash its pinkish hue. This material was probably redeposited from an adjacent combustion feature, possibly through sweeping, trampling, or a combination of both. (3) Caps the phosphatic ash and consists of 1.5-mm-sized fecal pellets, mixed with angular bone sand. This layer probably represents a period of abandonment, when rodents or small animal inhabited the cave, and anthropogenic input was relatively low. (4) Angular crushed bone, within a matrix of phosphatized material (MF type 5A). Phytoliths are rare or absent. This layer probably represents phosphatized ash that was reworked by sweeping or rake out from an adjacent combustion feature. It was most likely trampled, based on the presence of crushed bone fragments. (5) Massive charcoal and

inclusions ( $M F$ type 2). The fibrous material does not appear burned but at least partially humified.

Directly over the laminated material is a thin layer of massive woody and herbaceous charcoal (MF type 3). A rubefied zone, extending less than a centimeter deep, is located directly below the massive charcoal layer. A thin layer of yellowish phosphate is located on top of the charcoal and probably is phosphatized ash. This layer is not laterally extensive within the slide and interfingers with some fibrous organic material that is burnt (MF type 3). It probably represents an in situ hearth that was trampled, based on the presence of a large (centimeter size) bone that is snapped in situ. (6) Above (5), but the transition from (5) to (6) is not visible due to the subsampling of the blocks for thin sectioning. This layer consists of laminated organic material (MF type 2A). (7) Rich in phosphatized material (ashes) and contains some phytoliths (MF type 6A). The top of this layer is marked by a phosphatic crust, which appears broken and affected by bioturbation. This probably indicated a period of little anthropogenic input. (8) Loose, chaotically structured, and charcoal and charred fibrous organic material (MF type 3). The upper portion of this layer is affected by extensive authigenic gypsum formation. However, the presence of a phosphatic zone at the top of the layer, most likely representing phosphatized ash, supports the interpretation of this layer as an in situ hearth. (9) Generally, homogenous mixture of phosphatized material, with angular burnt bone sand, quartz grains, and fibrous organic material. This layer appears to have been reworked, possibly by sweeping or raking out of a combustion feature. Bioturbation and gypsum formation make it difficult to determine the structure of this layer

laminated fibrous matter. The material directly above the massive charcoal and phosphatized ash is laminated fibrous material, containing inclusions of éboulis, burnt bone, charcoal, and lithic fragments. This layer grades up into a layer of laminated phytoliths (MF type 4), which is in some places 2 to $3 \mathrm{~cm}$ thick. Its upper surface is marked by an erosional contact and is directly overlain by a massive layer of homogeneously mixed phosphate, bone, charcoal, and quartz sand. 
a sample 04-05 A-B
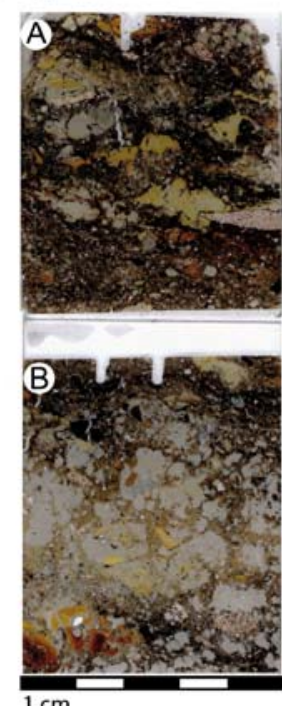

b

\section{sample SS-4}

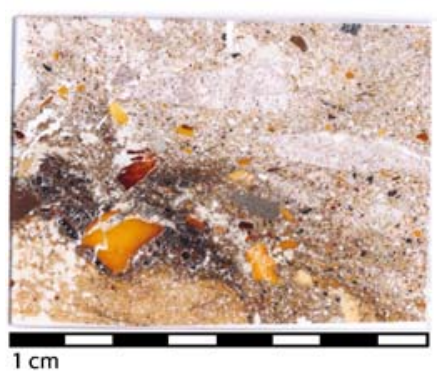

anthropogenic
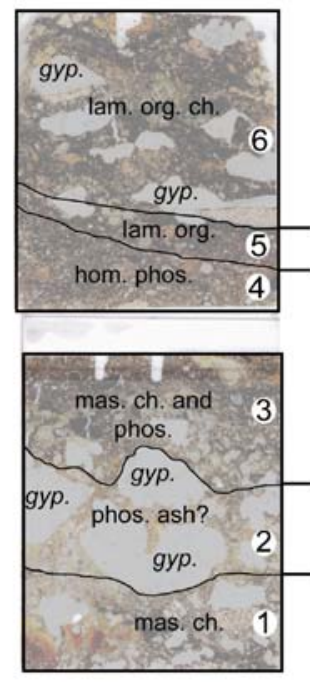

geogenic/biogenic

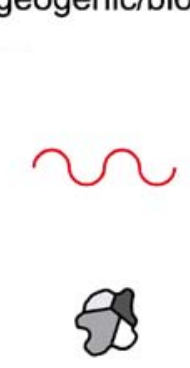

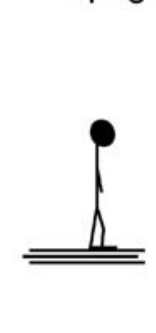

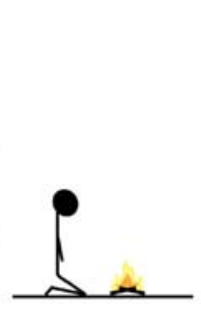

geogenic/biogenic

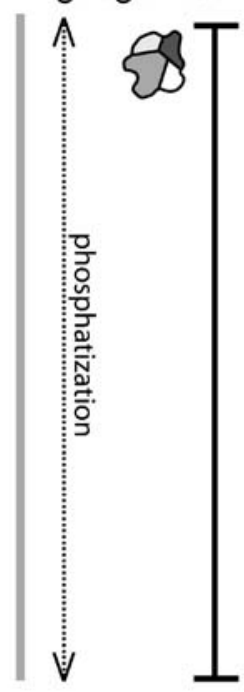


this case because the entire sequence YA2 to BSp was formed within a relatively short period of about 1,000 years at about $60 \mathrm{ka}$ (Jacobs et al. 2008). The laminated fibrous organic material directly above the crust is possibly sedge and/or grass that was transported to the cave by humans to use as some type of bedding and was extensively trampled. The massive charcoal layer above this bedding, with a rubefied base and overlying phosphatic ash, most likely represents an intact combustion feature (e.g., Goldberg et al. 2007; Meignen et al. 2007). The laminated fibrous material continues over the hearth feature, although, in contrast to the lowermost layer of laminated material, this one contains large centimeter-sized inclusions. Many of these inclusions, particularly charcoal and burnt bone, appear snapped or crushed in place. Such features have been taken to indicate the effects of trampling [e.g., at Pech de l'Azé IV (Dibble et al. 2009, submitted); and at Castanet (Goldberg 2007) both in the Dordogne, France]; trampling experiments have also produced crushed bone resembling that found at Sibudu (Miller et al. 2009). Often, the crushed bone and charcoal are spread out forming stringers that define a surface. Clasts of éboulis and lithic fragments from stone tool production are also oriented horizontally to subhorizontally, following the bedding plane defined by the microlaminations of the fibrous material.

Interesting to note is that the crushed bone stringers and other inclusions are not simply limited to a single bed or layer but are found throughout the layer of laminated fibrous material. This arrangement would suggest that there are numerous surfaces represented here that were subjected to trampling. One interpretation of these objects is that the fibrous material represents bedding, which was repeatedly built up and managed and that the oriented stringers and inclusions represent different surfaces. If this is the case, then it seems that bringing fibrous plant material (possibly sedges) into the cave did not occur as a single event but was repeated numerous times during the occupation as part of managing a surface or area.

Further evidence for management of the bedding is found in the charred and ashed upper portion of microfacies type 2 (found at the bottom section of sample SS-6A, Fig. 6). Here, the laminated fibrous material grades into and is capped by a layer of laminated phytoliths. It seems likely that this phytolith layer was produced by burning and ashing of the upper most portion of a grass or sedge "bed." Any ash present in this uppermost portion was subsequently phosphatized (as evidenced by the presence of phosphate "pockets" remaining within the phytolith layer). As the nonsiliceous remains were diagenetically altered, it seems that they were also removed from the phytolith layer.

The association of authigenic gypsum below the phytolith layer may be a result of the vertical translocation of carbonate and sulfate ions produced by the ashing process
(Schiegl and Conard 2006). The surface of the phytolith layer is marked by erosion. It is not unreasonable to imagine that an unconsolidated layer of phytoliths would easily be subjected to some type of erosion, be it natural (winnowing from wind) or anthropogenic (sweeping). The presence of a massive reworked layer of phosphatized ash, phytoliths, charcoal, burnt bone, and charcoal directly above the erosional surface would suggest that the erosion of the phytolith layer was probably produced by sweeping or some similar human activity.

Although the interpretation of sample SS-6 portrays a succession of events as represented by the sequence of microfacies, the situation is more complex than depicted here. The concept of microfacies, particularly as developed by Courty (2001), does not just simply entail vertical variation in microfacies type but also horizontal ones, which represent different spatially restricted activities or environments that may have occurred contemporaneously. This is certainly the case at Sibudu, where lateral variation is great and many discrete features are only traceable for tens of centimeters. Although a sequence of events is described as observed in the thin section, it should not be conceptualized that these activities occurred in isolation. All of the activities identified through interpretation of the microfacies, as presented above, probably occurred repeatedly during an individual occupation and in the immediately following one, which might have been a few decimeters away. Viewed as a whole, the combined activities as evidenced through the different microfacies consisted of the penecontemporaneous transport of plant material (sedges, reeds, grass, or possibly a combination of all three) for bedding and the construction of hearths. During an occupation, surfaces were managed through the adding of more plant material, the sweeping or raking out of extinguished hearths, and the burning of bedding. An example of the contemporaneity of different microfacies and lateral differences in specific activities can be found in sample SS-6B, where a rubefied base charcoal sequence of an intact hearth interfingers with a layer of laminated organic fibers (Fig. 6). As multiple, yet similar, occupations occurred in the rock shelter over time, these different activities and their corresponding microfacies were superposed over one another, forming the varied interbedded sequences seen in the thin sections and in the field.

\section{Consequences of this micromorphological study}

The degree of detail that we have been able to document above has significant ramifications for the study of other data sets at Sibudu and for archaeological sites in general. Specifically for Sibudu, the basis of the archaeometric study (Herries 2006) inferring past climates is not consistent with the micromorphological observations. We see 
little if any evidence for "... the input of derived soils by aeolian activity" (P. 131) nor for the input of background fire burning for this part of Africa. Furthermore, in light of the virtually complete anthropogenic character of the Sibudu sediments it is interesting to note:

Well defined hearths that are easily recognised can and must be avoided in sampling. Notwithstanding such precautions, background anthropogenic indicators may still occur in the MS [magnetic susceptibility] signal and this will complicate the results (Herries 2006: 145).

In this regard, it would seem that a full understanding of site formation processes needs to be gathered before interpretations can be made on the potential of a site to record climatic signals. Although the MS measurements taken at Sibudu certainly provide data, an incomplete understanding of the nature of deposition at the site and a lack of understanding of the basic components of the sediment being measured can lead one down the wrong interpretive path. For example, it may be that the MS results measured - at least in part - the ubiquitous burnt river valley clay aggregates. Although these aggregates could be considered as "derived soil," the micromorphological analysis shows that these components were brought to the cave by humans and not by processes directly associated with climatic conditions (Fig. 10).

The presence of "ochre" at Stone Age sites is a contentious issue, relating to the broader discussion of behavioral modernity (see, for instance, Henshilwood and Marean 2003). Although the topic of ochre at South African sites is too large to discuss in full here, it should be noted that very few discussions of ochre actually define what it is, other than a red substance used either for pigment or as a hafting material (Lombard 2006). In light of the presence of ubiquitous microscopic granules of red material identified as aggregates of river valley sediment transported by humans, almost certainly accidentally, to Sibudu, it seems necessary to reevaluate at least a part of what has been interpreted as "ochre" at South African sites. Red ochre (hematite- $\mathrm{Fe}_{2} \mathrm{O}_{3}$ ) thought to have been mixed with plant gum to create adhesive often occurs on stone tools in fairly large deposits that are even visible to the naked eye. Ground striated hematite nodules are fairly common in Sibudu and other Stone Age sites in southern Africa. The iron content of some of the archaeologically recovered Sibudu "ochres" was measured by S. Schiegl using Fourier transform infrared spectroscopy. A yellow piece of ochre from Gray under YA2 was identified as goethite $(\mathrm{FeOOH})$ and a red piece of ochre from the layer Gray Rocky was identified as hematite $\left(\mathrm{Fe}_{2} \mathrm{O}_{3}\right)$. However, incidental or scattered "ochre grains" that are not thought to be use-related sometimes occur on stone tools. Thus, when Lombard (2006) stated that "microscopic ochre granules are very small in comparison with the residues found on the tools, and are usually isolated single grains," it seems likely that at least a portion of these granules could be the burnt river valley clay aggregates that appear red in color (Fig. 11). Similar geological material may lead to the inflation of the occurrence of ochre as identified at other MSA sites. Based on our results, not all material that looks like ochre is ochre.

Finally, this microstratigraphic study has broader implications for specialist studies and how archaeology is practiced in general. In the field, one can perceive that the deposits are made up of not just combustion features but also some more diffuse combusted products. What becomes evident to a much greater extent in thin section, however, are the subtle differences among "burnt layers" as exemplified by sample SS-5 (Fig. 6) from layer OMOD, interpreted as a hearth complex (Wadley 2006). Here, we are able to monitor, for example, a complex succession of layers of phytoliths, phosphatic ashes, massive charcoal layers, phosphatic and calcareous ashes, laminated organic matter, all expressed at the centimeter scale. Most of these centimetric layers represent an individual occupation event or activity (e.g., burning) or perhaps associated events (e.g., sweeping, trampling). Whereas such lithosedimentary differences are worthily tracked in the field, it is not possible to individualize them as can be done in thin section.

The point here is not to criticize the meticulous research of our colleagues at the site but to underscore that, if archaeology wishes to advance beyond the synoptic view of reporting or examining major environmental shifts, we must look at the data in its proper anthropological contextthe context at which individual activities occur and are recorded - namely, the microlayer. By collapsing and combining individual and discrete contexts into broader analytical units, we only blur the anthropological contexts of the artifacts. This is particularly true for a site like Sibudu, where excellent preservation and careful excavation of individual contexts provide an ideal situation for evaluating discrete human activities.

\section{Concluding comments}

Most of the deposits in the rock shelter, Sibudu, are anthropogenic in character, with relatively lower amounts of geogenic ones such as inclusions of éboulis derived from rock fall. Even finer-grained materials, such as clay, were brought into the cave from the river valley by its former inhabitants. Micromorphological analysis of several of the Sibudu Cave deposits revealed that on a centimeter scale the remains of numerous anthropogenic events and activ- 

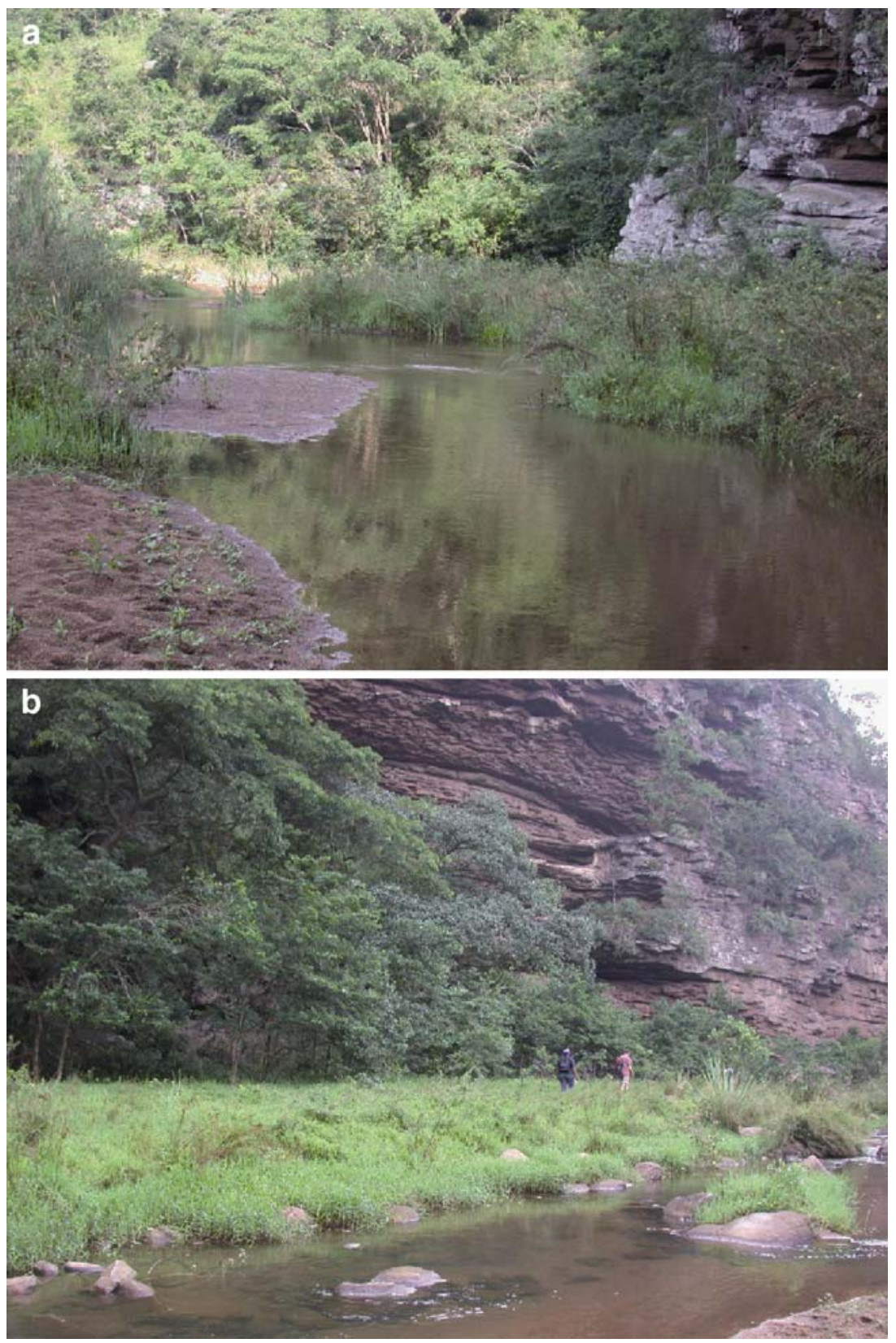

Fig. 10 a A view of the Tongati River near Sibudu Cave. b Another view of the Tongati River, with the bedded sandstones that form the rock shelter visible. Note the presence of running water, the reddish

ities are recorded. In fact, in the field, the large difference in sediments at roughly layer YA2 can be attributed to extensive trampling of the deposits below YA2 and not to natural diagenetic processes. The visible differences in the deposits above and below this layer, which is the base of the $\sim 60$ ka post-Howiesons Poort occupation, suggest that there was a major change in the type of occupation at Sibudu after the Howiesons Poort occupations after $60 \mathrm{ka}$ (Wadley and Jacobs 2006) as these lower deposits are composed essentially of compacted combustion products, but most of these are no longer in place. color of the sediment, and the presence of grasses and sedges. Vegetation and sediment removed from the river can be identified in thin section

Several hypotheses can be put forth to address these differences. The basic puzzle of this dichotomy is that both the laminated and massive units show evidence of trampling; however, the same anthropogenic process has produced different results. In the more massive units of the Howiesons Poort and earlier deposits, trampling has had the effect of homogenizing the units, whereas in the laminated post-Howiesons Poort and later deposits, trampling has compacted the original combustion deposits but did not transport them. Although the upper bedded layers show signs of bone crushing related to trampling, it is possible 


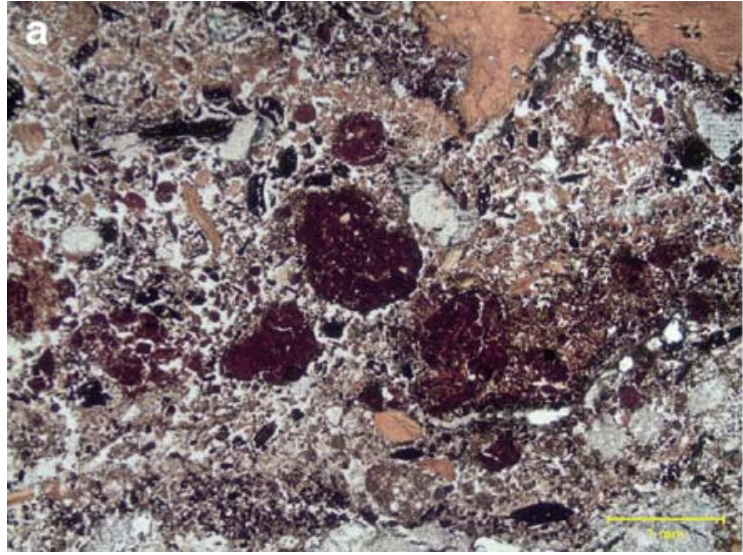

Fig. 11 a A group of fire-reddened clay and quartz silt aggregates derived from the local river valley. Here, they are found within MF type 3, suggesting either that they were either incorporated into a hearth attached to vegetation used for fuel or were accidentally tracked in to the cave by the inhabitants. From sample SS-5B. b A single aggregate from sample 04-4B. The size and reddish color of these

that the more homogeneous units accumulated more slowly, thus allowing for more trampling, other things being equal. As a consequence, discrete surfaces in these lower units would have been exposed for a longer period of time, allowing for a greater influence of trampling on the deposits, effectively homogenizing them. Conversely, a higher rate of deposition in the upper deposits would mean that trampling would have had a more limited effect, allowing for limited compaction of material and the crushing of individual components. Deposits, however, would have been buried before extensive trampling could have completely reworked and homogenized individual features. Evidence for lower sedimentation during the earlier periods at Sibudu is provided by the increased presence of mineral components in the homogeneous layers, as seen in thin section.

The scenario presented above has important ramifications. Since the vast majority of sediments at Sibudu result from anthropogenic deposition, the homogeneous Howiesons Poort and earlier layers, representing lower deposition rates, would suggest that there was an increase in the intensity of occupation at Sibudu during the postHowiesons Poort occupation. Another possible, but not mutually exclusive, hypothesis is that the use of sedge and/ or grass bedding influenced the effects of trampling on the different types of deposits. Sedge and/or grass bedding and subsequent management of the bedding would have stabilized surfaces, absorbing the pressure exerted on a surface by trampling and reducing the amount of material reworked by trampling. Evidence for this can be seen in thin section, where the laminated fibrous layers are compacted and show evidence of crushed and spread-out material on surfaces, but they lack the overall reworking of material seen in the homogeneous units. While it is

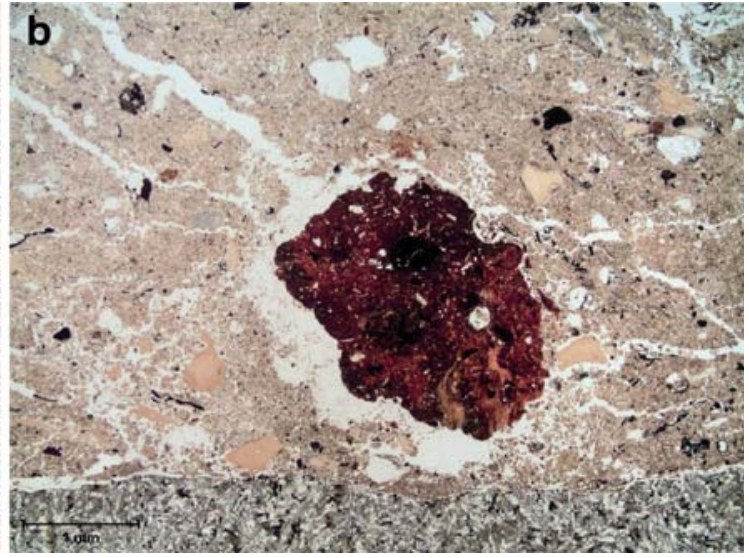

components may resemble what has been identified as "ochre." These components were brought to the cave by humans but most likely as sediment attached to sedges and/or grasses from the river valley. It seems unlikely that this material represents use of ochre, either for symbolic or functional uses

impossible to argue from negative evidence, the lower quantity of phytoliths noted in thin sections from the homogeneous layers and a decrease in sedge seeds in the lower sections may provide less direct evidence that sedges were not brought to the cave for bedding during the Howiesons Poort and earlier occupations.

The issue of bedding at Sibudu is an important one and deserves more detailed attention. The use of plant material for bedding in caves and rock shelters has a long history, particularly in South Africa. Since the 1950s, excavators at South African caves have described stratified sites that, in their opinion, contained evidence for preserved grass bedding. These sites span the time scale from recent historic situations (Walton 1951; Stannard 1965) to Iron Age deposits (Parkington and Poggenpoel 1971; Van Rijssen and Avery 1992) and Later Stone Age (Binneman 1997, 1998, 1999, 2000; Wadley 1976; Wells 1965).

Although some of these instances are clear, particularly in later contexts, the presence of bedding in earlier Middle Stone Age deposits is not conclusively shown in the reports. Recently, Sievers and Wadley (2008) have suggested that, in Sibudu, the high frequencies of sedge nutlets (Schoenoplectus cf. brachyceras) in the laminated deposits, particularly the $\sim 50-\mathrm{ka}$ layers OMOD and MOD, are the result of humans bringing in local sedges for bedding or matting, noting that sedge is commonly used for woven mats today (Van Wyk and Gericke 2000). The micromorphological evidence, along with preliminary phytolith identification (Arlene Rosen 2008, personal communication), presented in this study supports the interpretation of Sievers and Wadley (2008) and provides direct evidence to show that plant materials, most likely sedges, were brought to the cave to serve as bedding. 
The methodology of micromorphology, coupled with the excellent preservation at Sibudu, allows for a detailed analysis of complex activities and behaviors: something not previously achieved for Pleistocene sites. As such, the level of detail may make it tempting to see this behavior as exceptionally complex, particularly when compared to the coarser, and stratigraphically lower, homogeneous layers. Before this change is interpreted as an increase in complex behavior at Sibudu, several caveats must be stated. The construction and maintenance of bedding, through repeated construction during a single occupation and also through occasional burning of the bedding, are behaviors not previously described for the MSA. Furthermore, the identification of different and distinct microfacies, representing not only bedding construction and maintenance but also hearth construction and sweeping and dumping, shows that numerous activities occurred during single occupations, and these activities occurred within localized spaces. This is particularly evident in sample SS-6, where the laminated plant material shows evidence of repeated construction during a single occupation.

Organization of living space, and particularly a deliberate use of space, has been suggested by Wadley (2001) and also Binford (1996) as an important trait of culturally modern behavior, reflecting a more complex social organization. While the evidence from the laminated units at Sibudu may reflect such organization, the lack of evidence for such spatial organization, such as is the case for the lower homogeneous layers at Sibudu, should not automatically suggest that occupation in these units was any less complex. Even if the hypothesis that the construction of bedding in the upper levels is the main reason for the difference in structure of the homogeneous and laminated units at Sibudu is correct, we cannot make any conclusive statements about the complexity of the occupation for the lower units. In order to test such hypotheses and ideas, more caves with similar stratigraphy to Sibudu's should be the subject of micromorphological analysis. More systematic studies of exposed deposits from Sibudu in the future should also reveal more clearly spatial and temporal differences — or similarities — within the site.

Acknowledgements Financial support for this research was provided in part by a Deutsche Forshungsgemeinschaft (DFG) Grant CO226/ 31-1 to S. Schiegl and N. Conard; a graduate student grant by the Deutsche Akademische Austauschdienst (DAAD) to C. Miller; the US National Science Foundation Grant to P. Goldberg (BCS \#0551927); and the support by a Marie Curie International Fellowship within the 6th European Community Framework Program to F. Berna (\# MOIFCT-2006-041053). A. Rosen provided some valuable preliminary determinations of phytoliths, and K. Deckers helped to identify some charcoal remains. Johan Binneman courteously provided much difficult-to-locate information about the use of grass matting from archaeological contexts in South Africa.

\section{References}

Berna F, Goldberg P (2007) Assessing Paleolithic pyrotechnology and associated hominin behavior in Israel. Israel J Earth Sci 56:107-121

Berna F, Behar A, Shahack-Gross R, Berg J, Zorn J, Boaretto E, Gilboa A, Sharon I, Shalev S, Silshtein S, Weiner S (2007) Sediments exposed to high temperatures: reconstructing pyrotechnological practices in late Bronze and Iron Age strata at Tel Dor (Israel). J Archaeol Sci 34:358-373

Binford LR (1996) Hearth and home: the spatial analysis of ethnographically documented rock shelter occupations as a template for distinguishing between human and hominid use of sheltered space. In: Conard NJ, Wendorf F (eds) Middle Paleolithic and Middle Stone Age settlement systems. A.B.A.C. O. Edizioni, Forli, pp 229-239

Binneman J (1997) Results from a test excavation at the Havens Cave, Cambria Valley, South-eastern Cape. South Afr Field Archaeol 6:93-105

Binneman J (1998) Results from a test excavation at Kleinpoort Shelter in the Bavianskloof, Eastern Cape Province. South Afr Field Archaeol 7:90-97

Binneman J (1999) Results from a test excavation at Groot Kommandokloof Shelter in the Baviaanskloof/Kouga Region, Eastern Cape Province. South Afr Field Archaeol 8:100-107

Binneman J (2000) Results from two test excavations in the Baviaanskloof Mountains, Eastern Cape Province. South Afr Field Archaeol 9:83-96

Brochier JE, Thinon M (2003) Calcite crystals, starch grains aggregates or... POCC? Comment on 'calcite crystals inside archaeological plant tissues'. J Archaeol Sci 30:1211-1214

Cain CR (2005) Using burned bone to look at Middle Stone Age occupation and behavior. J Archaeol Sci 32:873-884

Canti MG (2003) Aspects of the chemical and microscopic characteristics of plant ashes found in archaeological soils. Catena 54:339-361

Courty M-A (2001) Microfacies analysis assisting archaeological stratigraphy. In: Goldberg P, Holliday VT, Ferring CR (eds) Earth sciences and archaeology. Kluwer Academic/Plenum, New York, pp 205-239

Courty M-A, Goldberg P, Macphail RI (1989) Soils and micromorphology in archaeology. Cambridge University Press, Cambridge

Flügel E (2004) Microfacies of carbonate rocks: analysis, interpretation and application. Springer, Berlin

Goldberg P (2007) Micromorphologie. In: White R (ed) Abris Castanet, secteurs sud et nord (Commune de Sergeac, Dordogne) Rapport de fouille programmée Année 2007, pp 16-18

Goldberg P, Macphail R (2003) Strategies and techniques in collecting micromorphology samples. Geoarchaeology 18(5):571-578

Goldberg P, Macphail RI (2006) Practical and theoretical geoarchaeology. Blackwell Scientific, Oxford

Goldberg P, Laville H, Meignen L (2007) Stratigraphy and geoarchaeological history of Kebara Cave, Mount Carmel. In: BarYosef O, Meignen L (eds) Kebara Cave, vol 2. Peabody Museum, Cambridge

Henshilwood CS, Marean CW (2003) The origin of modern human behavior: a review and critique of models and test implications. Curr Anthropol 44(5):627-651

Herries AIR (2006) Archaeomagnetic evidence for climate change at Sibudu Cave. South Afr Humanities 18(1):131-147

International Committee for Coal and Organic Petrology (ICCP) (2001) The new inertinite classification (ICCP System 1994). Fuel 80(4):459-471

Jacobs Z, Wintle AG, Duller GAT, Roberts RG, Wadley L (2008) New ages for the post-Howiesons Poort, late and final Middle Stone Age at Sibudu, South Africa. J Archaeol Sci 35:1790-1807 
Karkanas P, Goldberg P (2009) Site formation processes in Site PP13B (Pinnacle Point, South Africa): resolving stratigraphic and depositional complexities with micromorphology. J Hum Evol (in press)

Ligouis B (2006) Jais, lignite, charbon et autres matières organiques fossiles: application de la pétrologie organique à l'étude des éléments de parure et des fragments bruts. In Bullinger J, Leesch D, Plumettaz N (eds) Le site magdalénien de Monruz, 1. Premiers éléments pour l'analyse d'un habitat de plein air. Neuchâtel, Service et Musée cantonal d'archéologie, Archéologie neuchâteloise, vol. 33, pp 197-216

Lombard M (2006) First impressions of the functions and hafting technology of Still Bay pointed artefacts from Sibudu Cave. South Afr Humanit 81(1):27-41

Macphail RI, Courty MA, Hather J, Wattez J (1997) The soil micromorphological evidence of domestic occupation and stabling activities. In: Maggi R (ed) Arene Candide: a functional and environmental assessment of the Holocene sequence (Excavations Bernabò Brea-Cardini 1940-50). Memorie dell'Istituto Italiano di Paleontologia Umana, Roma, pp 53-88

Meignen L, Goldberg P, Bar-Yosef O (2007) The hearths at Kebara Cave and their role in site formation processes. In: Bar-Yosef $\mathrm{O}$, Meignen L (eds) The Middle and Upper Paleolithic archaeology of the Kebara Cave, Mt Carmel, Israel. Peabody Museum, Harvard University, Cambridge, pp 91-122

Miller CE, Conard NJ, Goldberg P, Berna F (2009) Dumping, sweeping and trampling: experimental micromorphological analysis of anthropogenically modified combustion features. Paléthologie (in press)

Nadel D, Weiss E, Simchoni O, Tsatskin A, Danin A, Kislev M (2004) Stone Age hut in Israel yields world's oldest evidence of bedding. Proc Natl Acad Sci 101(17):6821-6826

Parkington J, Poggenpoel C (1971) Excavations at De Hangen, 1968. South Afr Archaeol Bull 26(101/102):3-36

Pickering R (2006) Regional geology, setting and sedimentology of Sibudu Cave. South Afr Humanit 18(1):123-129

Schiegl S, Conard NJ (2006) The Middle Stone Age sediments at Sibudu: results from FTIR spectroscopy and microscopic analyses. South Afr Humanit 18(1):149-172

Schiegl S, Goldberg P, Bar-Yosef O, Weiner S (1996) Ash deposits in Hayonim and Kebara caves, Israel: macroscopic, microscopic, and mineralogical observations and their archaeological implications. J Archaeol Sci 23:763-781
Schiegl S, Ligouis B, Conard NJ, Goldberg P (2004) Mineralogy, micromorphology, phytolith analysis and organic petrology of Middle Palaeolithic and MSA Cave Sites: comparison between Sibudu (South Africa) and the Levant. In Geoarchaeology of the Eastern Mediterranean. University of Tübingen, July, 2004

Shahack-Gross R, Berna F, Karkanas P, Weiner S (2004) Bat guano and preservation of archaeological remains in cave sites. $\mathrm{J}$ Archaeol Sci 31(9):1259-1272

Sievers C (2006) Seeds from the Middle Stone Age layers at Sibudu Cave. South Afr Humanities 18(1):203-222

Sievers C, Wadley L (2008) Going underground: experimental carbonization of fruiting structures under hearths. J Archaeol Sci 35(11):2909-2917

Stannard C (1965) A report on preliminary excavations in Tarzan's Cave, Simonstown. S Afr Archaeol Bull 20(78):91-93

Stoops G (2003) Guidelines for analysis and description of soil and regolith thin sections. Soil Science Society of America, Madison

Taylor GH, Teichmüller M, Davis A, Diessel CFK, Littke R, Robert P (1998) Organic Petrology. Gebrüder Bornträger, Berlin

van Rijssen WJ, Avery G (1992) The late Holocene deposits at Klein Kliphuis Shelter, Cedarberg, Western Cape Province. S Afr Archaeol Bull 47(155):34-43

van Wyk BE, Gericke N (2000) People's plants: a guide to useful plants of southern Africa. Briza, Pretoria

Wadley L (1976) Radiocarbon dates from big elephant shelter, Erongo Mountains, South West Africa. S Afr Archaeol Bull 31(123/ 124): 146

Wadley L (2001) What is cultural modernity? a general view and a South African perspective from Rose Cottage Cave. Camb Archaeol J 11(2):201-221

Wadley L (2006) Partners in grime. South Afr Humanities 18(1):315341

Wadley L, Jacobs Z (2004) Sibudu Cave, KwaZulu-Natal: background to the excavations of Middle Stone Age and Iron Age occupations. South Afr J Sci 100:145-151

Wadley L, Jacobs Z (2006) Sibudu Cave: background to the excavations, stratigraphy and dating. South Afr Humanities 18 (1): $1-26$

Walton J (1951) Occupied rock shelters in Basutoland. S Afr Archaeol Bull 6(21):9-13

Wells MJ (1965) An analysis of plant remains from Scott's Cave in the Gamtoos Valley. S Afr Archaeol Bull 20(78):79-84 